\title{
Article \\ The Anti-Cancer Effects of a Zotarolimus and 5-Fluorouracil Combination Treatment on A549 Cell-Derived Tumors in BALB/c Nude Mice
}

\author{
Ching-Feng Wu ${ }^{1}$, Ching-Yang Wu ${ }^{1}$, Robin Y.-Y. Chiou ${ }^{2}$, Wei-Cheng Yang ${ }^{3}$, Chuen-Fu Lin ${ }^{4}$, Chao-Min Wang ${ }^{5} \mathbb{D}$, \\ Po-Hsun Hou ${ }^{6,7}$, Tzu-Chun Lin ${ }^{5}$, Chan-Yen Kuo ${ }^{8, * \mathbb{D}}$ and Geng-Ruei Chang ${ }^{5, *(D)}$
}

1 Division of Thoracic and Cardiovascular Surgery, Department of Surgery, Chang Gung Memorial Hospital, Chang Gung University, Linkou, 5 Fuxing Street, Guishan District, Taoyuan 33305, Taiwan: maple.bt88@gmail.com (C.-F.W.); wu.chingyang@gmail.com (C.-Y.W.)

2 Department of Food Science, National Chiayi University, 300 University Road, Chiayi 60004, Taiwan; rychiou@mail.ncyu.edu.tw

3 Department of Veterinary Medicine, School of Veterinary Medicine, National Taiwan University, 4 Section, 1 Roosevelt Road, Taipei 10617, Taiwan; yangweicheng@ntu.edu.tw

4 Department of Veterinary Medicine, College of Veterinary Medicine, National Pingtung University of Science and Technology, 1 Shuefu Road, Neipu, Pingtung 912301, Taiwan; cflin2283@mail.npust.edu.tw

5 Department of Veterinary Medicine, National Chiayi University, 580 Xinmin Road, Chiayi 60054, Taiwan; leowang@mail.ncyu.edu.tw (C.-M.W.); lin890090@gmail.com (T.-C.L.)

6 Department of Psychiatry, Taichung Veterans General Hospital, 4 Section, 1650 Taiwan Boulevard, Taichung 40705, Taiwan; peterhopo2@yahoo.com.tw

updates

Citation: Wu, C.-F.; Wu, C.-Y.; Chiou, R.Y.-Y.; Yang, W.-C.; Lin, C.-F.; Wang, C.-M.; Hou, P.-H.; Lin, T.-C.; Kuo, C.-Y.; Chang, G.-R. The Anti-Cancer Effects of a Zotarolimus and 5-Fluorouracil Combination Treatment on A549 Cell-Derived Tumors in BALB/c Nude Mice. Int. J. Mol. Sci. 2021, 22, 4562. https:// doi.org/10.3390/ijms22094562

Academic Editor: Silvie Rimpelova

Received: 1 March 2021

Accepted: 23 April 2021

Published: 27 April 2021

Publisher's Note: MDPI stays neutra with regard to jurisdictional claims in published maps and institutional affiliations.

Copyright: (C) 2021 by the authors Licensee MDPI, Basel, Switzerland This article is an open access article distributed under the terms and conditions of the Creative Commons Attribution (CC BY) license (https:// creativecommons.org/licenses/by/ $4.0 /)$
7 Faculty of Medicine, National Yang-Ming University, 2 Section, 155 Linong Street, Beitou District, Taipei 11221, Taiwan

8 Department of Research, Taipei Tzu Chi Hospital, Buddhist Tzu Chi Medical Foundation, 289 Jianguo Road, Xindian District, New Taipei City 231405, Taiwan

* Correspondence: cykuo863135@gmail.com (C.-Y.K.); grchang@mail.ncyu.edu.tw (G.-R.C.) Tel.: +886-2-66289779 (C.-Y.K.); +886-5-2732946 (G.-R.C.)

Abstract: Zotarolimus is a semi-synthetic derivative of rapamycin and a novel immunosuppressive agent used to prevent graft rejection. The pharmacological pathway of zotarolimus restricts the kinase activity of the mammalian target of rapamycin (mTOR), which potentially leads to reductions in cell division, cell growth, cell proliferation, and inflammation. These pathways have a critical influence on tumorigenesis. This study aims to examine the anti-tumor effect of zotarolimus or zotarolimus combined with 5-fluorouracil (5-FU) on A549 human lung adenocarcinoma cell line implanted in $\mathrm{BALB} / \mathrm{c}$ nude mice by estimating tumor growth, apoptosis expression, inflammation, and metastasis. We established A549 xenografts in nude mice, following which we randomly divided the mice into four groups: control, 5-FU (100 mg/kg/week), zotarolimus ( $2 \mathrm{mg} / \mathrm{kg} /$ day), and zotarolimus combined with 5-FU. Compared the results with those for control mice, we found that mice treated with zotarolimus or zotarolimus combined with 5-FU retarded tumor growth; increased tumor apoptosis through the enhanced expression of cleaved caspase 3 and extracellular signal-regulated kinase (ERK) phosphorylation; decreased inflammation cytokines levels (e.g., IL-1 $\beta$, TNF- $\alpha$, and IL-6); reduced inflammation-related factors such as cyclooxygenase-2 (COX-2) protein and nuclear factor- $\kappa \mathrm{B}$ (NF- $\mathrm{kB}$ ) mRNA; enhanced anti-inflammation-related factors including IL-10 and inhibitor of NF-kB kinase $\alpha$ $(\mathrm{I} \kappa \mathrm{B} \alpha) \mathrm{mRNA}$; and inhibited metastasis-related factors such as transforming growth factor $\beta$ (TGF- $\beta$ ), CD44, epidermal growth factor receptor (EGFR), and vascular endothelial growth factor (VEGF). Notably, mice treated with zotarolimus combined with 5-FU had significantly retarded tumor growth, reduced tumor size, and increased tumor inhibition compared with the groups of mice treated with 5 -FU or zotarolimus alone. The in vivo study confirmed that zotarolimus or zotarolimus combined with 5-FU could retard lung adenocarcinoma growth and inhibit tumorigenesis. Zotarolimus and 5-FU were found to have an obvious synergistic tumor-inhibiting effect on lung adenocarcinoma. Therefore, both zotarolimus alone and zotarolimus combined with 5-FU may be potential anti-tumor agents for treatment of human lung adenocarcinoma. 
Keywords: apoptosis; 5-Fluorouracil; lung adenocarcinoma; inflammation; metastasis; zotarolimus

\section{Introduction}

The vast majority of lung cancers are caused by epithelial cell lesions resulting from malignant epithelial tumors of the lung. Lung cancer is a leading cause of cancer-related deaths among men and women worldwide [1]. Globally, lung cancer causes about 1.8 million deaths each year [2]. Common symptoms include shortness of breath, coughing (hemoptysis), and weight loss. Lung cancer is mainly divided into two broad histological subtypes: non-small-cell lung cancer (NSCLC), including lung adenocarcinoma and lung squamouscell carcinoma, and small-cell lung cancer (SCLC). These are categorized by the type of cell in which the cancer originates [3]. The most common type of lung cancer is NSCLC, which has high morbidity and mortality rates [4]. Related treatments and prognosis plans are created on the basis of the histological type of cancer, cancer stage, and patient status. Possible treatment options are surgery, chemotherapy, and radiotherapy [3,5]. Chemotherapy is the application of chemicals or drugs to kill cancer cells. Commonly administered anticancer drugs include alkylating agents (e.g., cisplatin), mitotic inhibitors (e.g., paclitaxel), epidermal growth factor receptor (EGFR) inhibitors (e.g., gefitinib), vascular endothelial growth factor (VEGF), or VEGF receptor inhibitors (e.g., bevacizumab) [6].

The mammalian target of rapamycin (mTOR) is a serine-threonine protein kinase expressed in all cells. mTOR regulates cell transcription, translation, cell growth, cell arrangement, cell differentiation, and apoptosis [7]. The mTOR pathway is important for growth development, and its signaling is involved in insulin signaling, growth factors, nutrition, energy metabolism, obesity, cancer, and other diseases [8-10]. Tuberous sclerosis 1 and 2 (TSC1 and TSC2) are upstream of the mTOR pathway and can hydrolyze GTP into GDP, rendering mTOR inactive and blocking the mTOR signaling pathway. However, activated mTOR phosphorylates S6K (ribosomal protein S6 kinase, p70S6K), which initiates a series of related cellular physiological responses including vascular and tumor cell proliferation and other pathways related to tumor formation [11]. mTOR activation promotes protein translation, enhances cell growth, and affects intracellular metabolism [12]. Therefore, the development of new drugs to inhibit mTOR activation is important, and these novel drugs can serve as new approaches for the treatment of tumors.

Zotarolimus is an analogue of rapamycin, an immunosuppressive drug. Rapamycin prevents allograft rejection and is used in drug-eluting stents (DESs) to reduce postangioplasty restenosis $[13,14]$. Rapamycin, however, can produce adverse effects such as immunodeficiency and hypertension as well as cardiac and vascular, lipid metabolic, testicular and epididymal, dermatological, obstetric and gynecological, ocular, and neurological problems $[15,16]$. Continual administration of zotarolimus is safer than that of rapamycin, with lower risks for metabolic, diabetic, and hyperclycemic adverse events $[9,16,17]$. Zotarolimus was the first cytostatic agent to be used primarily for DES delivery [18]; in zotarolimus, a tetrazole ring replaces the hydroxyl group found at position 42 in rapamycin, which makes zotarolimus highly lipophilic. As a result, zotarolimus has a significantly greater octanol-water partition coefficient than other drugs used in DESs. Drug-loaded stents enable drugs from the stent to be gradually released into the coronary artery wall and the properties of zotarolimus provide several advantages on this application. Additionally, its lipophilic nature may favor the crossing of cell membranes to restrict the neointimal proliferation of target tissues. A majority of research on the use of zotarolimus focuses on the treatment of cardiovascular diseases, and little research has been addressed to its potential use for other diseases $[19,20]$. Everolimus, also a mTOR inhibitor, reduces the expression of VEGF in tumor-derived mouse ovarian carcinoma and in gastric cancer cells in vitro. In vivo, everolimus considerably restricts tumor growth $[21,22]$. In addition, everolimus has been used to treat pancreatic, bladder, and lung cancers [23-25]. Zotarolimus, exhibiting a similar mechanism of action to everolimus, could be used in the treatment of 
lung cancer [26]. For lung cancer treatment, 5-fluorouracil (5-FU) is also widely used [27], although potential drug resistance limits the clinical use of 5-FU. Studies have reported that the anticancer efficacy of 5-FU increased with the dose [28,29], but the cytotoxic effect on normal cells induced unacceptable levels of toxicity in patients [30]. To overcome this, 5-FU should be combined with other anticancer drugs with different mechanistic actions [28].

Patients with lung cancer are mainly treated with chemotherapy. However, certain patients do not respond to this therapy or may respond well initially but gradually show signs of a relapse. This results in increased drug doses, which may cause adverse drug reactions or the development of drug resistance [31]. Thus, developing new drugs or a combination of drugs for the treatment of lung cancer is crucial. Although the pyrimidine analog 5-FU is widely used to treat cancers, consequent drug resistance seriously limits its clinical use in lung cancer treatment [27]. Therefore, this study examined the antitumor effects of the mTOR inhibitor zotarolimus on A549 cells as well as the synergistic effects of zotarolimus when combined with 5-FU. The examination was conducted on an A549 human lung adenocarcinoma cell line implanted into BALB/c nude mice. We observed tumor growth and various aspects of factors related to tumor development, including apoptosis, inflammation, and metastasis, to explore the therapeutic properties of zotarolimus and mTOR drugs for lung cancer and thereby increase the number of available drugs for lung cancer treatment choices.

\section{Results}

\subsection{Zotarolimus Retards Tumor Growth}

The previous study suggests that 5-FU and zotarolimus have anticancer activity $[27,28]$. Accordingly, we observed reduced tumor growth and volume in the groups treated with 5-FU alone, zotarolimus alone, and a combination of zotarolimus and 5-FU compared with the control group (Figure 1a). In addition, the time course of responses revealed a significant greater decrease in tumor growth in the mice treated with 5-FU $(p<0.001)$, zotarolimus $(p<0.05)$, and zotarolimus combined with 5-FU $(p<0.001)$ than that in the control mice (Figure 1b). Combining zotarolimus with 5-FU led to a greater decrease in tumor growth, representing an obvious synergistic function. Compared to the control group, the tumor inhibition rate increased by $50.0 \%$ in the 5-FU-treated group, $31.2 \%$ in the zotarolimus-treated group and $66.7 \%$ in the group treated with zotarolimus combined with 5-FU (Table 1). Therefore, zotarolimus combined with 5-FU was a powerful inhibitor of the growth of lung adenocarcinoma.

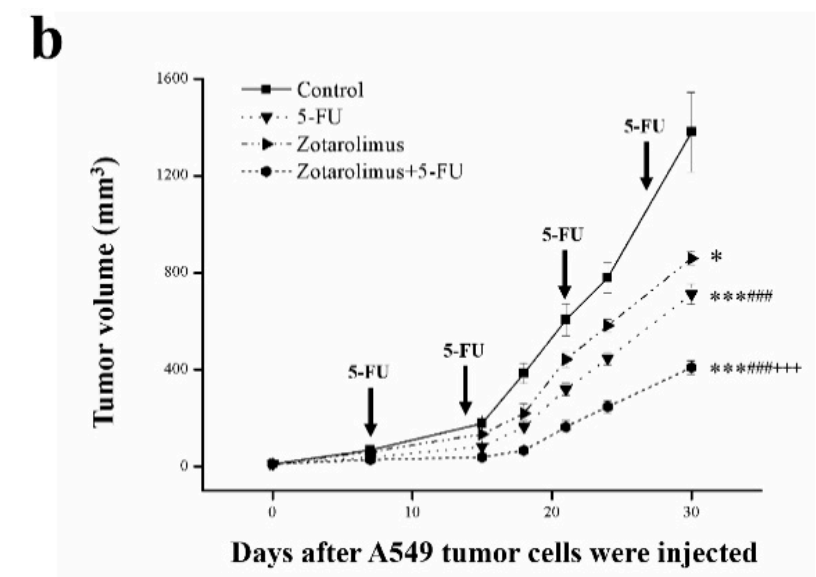

Figure 1. Relative volume of tumors. (a) Photographs of tumors excised after sacrifice on day 30. (b) Volumes of the A549 tumor masses from BALB/cByJNarl mice given different treatments: control (saline), 5-FU (100 mg/ kg/week), zotarolimus ( $2 \mathrm{mg} / \mathrm{kg} /$ day), and zotarolimus ( $2 \mathrm{mg} / \mathrm{kg} /$ day) combined with 5-FU (100 mg/ kg/week). All data are presented as mean \pm standard deviation, $n=7$ per group. ${ }^{*} p<0.05$ and ${ }^{* *} p<0.001$ compared with the control group. ${ }^{\# \#} p<0.001$ compared with the 5-FU-treated group. ${ }^{+++} p<0.001$ compared with the zotarolimus-treated group. All treatments were initiated on day 7 when tumors were detected. 
Table 1. Weight of the tumors from BALB/cByJNarl mice after sacrifice.

\begin{tabular}{ccc}
\hline & Tumor Weight (g) & Tumor Inhibition Rate (\%) \\
\hline Control & $1.248 \pm 0.082$ & - \\
5-FU & $0.687 \pm 0.033^{* * *}$ & 50.0 \\
Zotarolimus & $0.859 \pm 0.035^{* * * \#}$ & 31.2 \\
Zotarolimus + 5-FU & $0.416 \pm 0.026^{* * * \# \#+++}$ & 66.7 \\
\hline
\end{tabular}

All data are presented as mean \pm standard deviation, $n=7$. ${ }^{* * *} p<0.001$ compared with control group. ${ }^{\# \#} p<0.01$ and $^{\# \# \#} p<0.001$ compared with 5-FU-treated group. ${ }^{+++} p<0.001$ compared with the zotarolimus-treated group.

\subsection{Zotarolimus Increases the Number of TUNEL-Positive Cells}

The TUNEL assay is designed to detect apoptotic cells, which are subjected to extensive DNA degradation during the late apoptosis stages [7]. Our findings indicated that TUNEL positive cells increased $5.5(p<0.001), 3.3(p<0.001)$, and $9.2(p<0.001)$ times (Figure $2 b)$ in mice treated with 5-FU, zotarolimus, and zotarolimus combined with 5-FU, respectively (Figure 2a). These values were significantly greater than those observed for the control group. The zotarolimus-treated group exhibited significantly lower TUNEL-positive cells than did the 5-FU-treated group. Moreover, the number of TUNEL-positive cells in mice treated with zotarolimus-only group was lower than those in mice treated with 5-FU-only group (by $40.8 \%$ ) and the zotarlimus and 5-FU combined group (by $64.3 \%$ ). These results indicated that both zotarolimus and a combination of zotarolimus and 5-FU increased the degree of apoptosis, and the combination treatment with zotarolimus and 5-FU had the greatest effect.

\subsection{Zotarolimus Increases Apoptosis-Related Protein Expression}

Apoptotic activation results in the activation or inactivation of different substrates, stimulating a cascade of signaling events that control the degradation of cellular components [32]. We selected apoptosis-related proteins, including cleaved caspase 3, extracellular signal-regulated kinase (ERK), phosphorylated ERK, and anti-apoptosis protein B-cell lymphoma 2 (Bcl-2), for analysis (Figure 3a). Using western blotting, we found that the expression of cleaved caspase 3 and phosphorylated ERK was significantly higher in the groups treated with 5-FU (cleaved caspase 3: $p<0.001$; phosphorylated ERK: $p<0.001$ ) and zotarolimus combined with 5-FU (cleaved caspase 3: $p<0.001$; phosphorylated ERK: $p<0.001$ ) than in the control group (Figure $3 \mathrm{~b}, \mathrm{c}$ ). In addition, zotarolimus-treated mice had a higher level of cleaved caspase $3(p<0.001)$ and ERK phosphorylation $(p<0.01)$ than control mice. In contrast, the 5-FU and zotarolimus-treated groups had a lower expression of cleaved caspase 3 (5-FU: $p<0.01$; zotarolimus: $p<0.001$ ) and ERK phosphorylation (5-FU: $p<0.001$; zotarolimus: $p<0.001$ ) than zotarolimus combined with 5-FU-treated group. Mice treated with zotarolimus combined with 5-FU had the highest expression of cleaved caspase 3 and ERK phosphorylation. Bcl-2 is widely considered a suppressor of apoptosis. Bcl-2 expression in the 5-FU $(p<0.001)$ and zotarolimus groups $(p<0.001)$ was lower than in the control group (Figure 3d). However, Bcl-2 expression in the zotarolimus group was higher than in the 5-FU-treated group $(p<0.01)$ and in the group treated with zotarolimus combined with 5-FU $(p<0.001)$, which had the lowest Bcl-2 expression. The results indicated that zotarolimus and zotarolimus combined with 5-FU could enhance the expression of apoptosis-related proteins and inhibit anti-apoptotic protein expression. Furthermore, zotarolimus combined with 5-FU exhibited the maximum effect on apoptosis. 

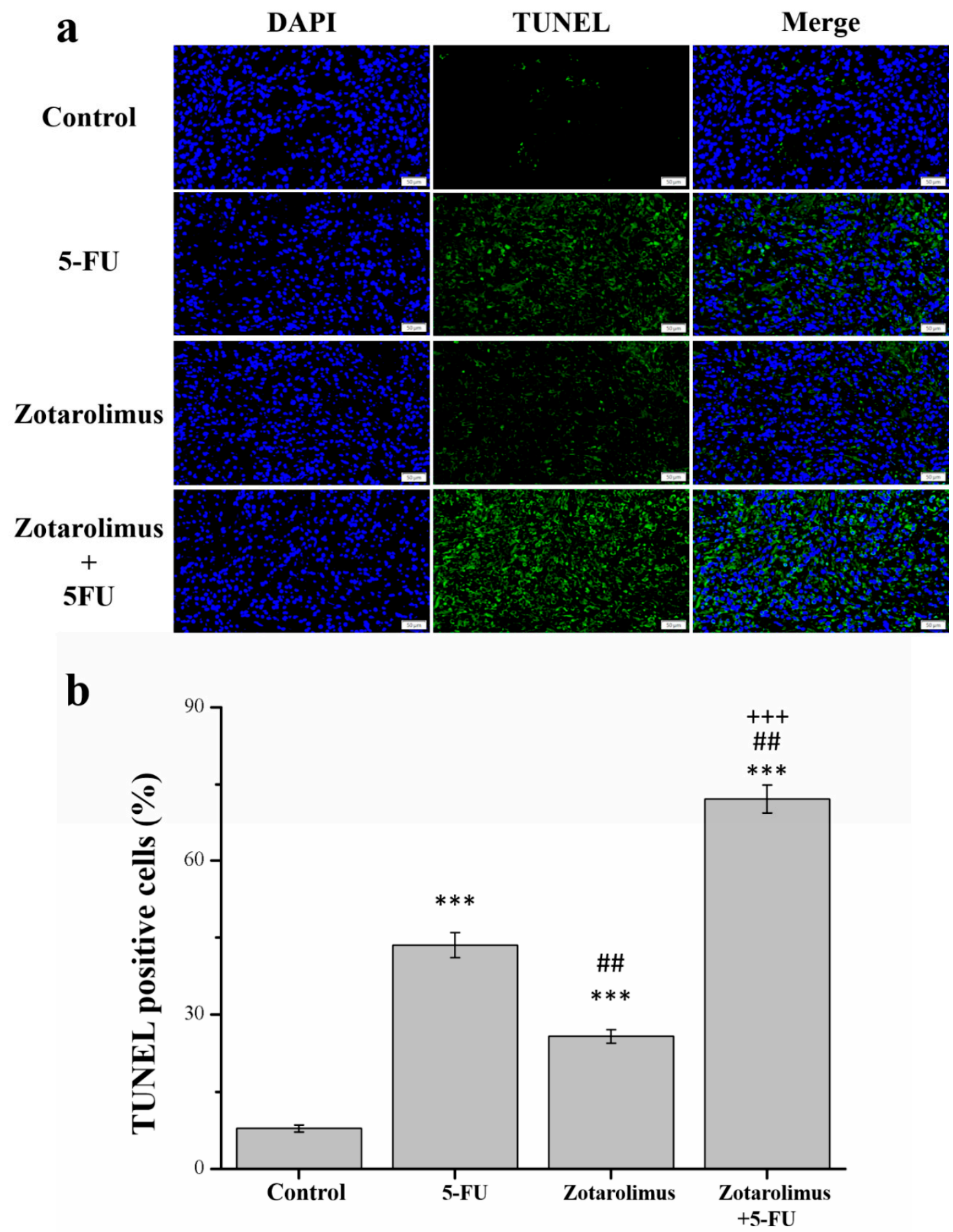

Figure 2. Analysis of apoptosis in A549 tumors by TUNEL/DAPI staining $(\times 200)$. (a) Images of TUNEL and DAPI staining and merge. (b) The percentage of TUNEL positive cells in the A549 tumor mass of control BALB/cByJNarl mice and mice given different treatments: 5-FU (100 mg/kg/week), zotarolimus ( $2 \mathrm{mg} / \mathrm{kg} /$ day), and zotarolimus $(2 \mathrm{mg} / \mathrm{kg} / \mathrm{day})$ combined with 5-FU (100 mg/kg/week). All data are presented as mean \pm standard deviation, $n=7$ per group. ${ }^{* * *} p<0.001$ compared with the control group. ${ }^{\# \#} p<0.01$ compared with the 5 -FU-treated group. ${ }^{+++} p<0.001$ compared with the zotarolimus-treated group. All treatments were started on day 7 when tumors were detected. Scale bars $=50 \mu \mathrm{m}$. 

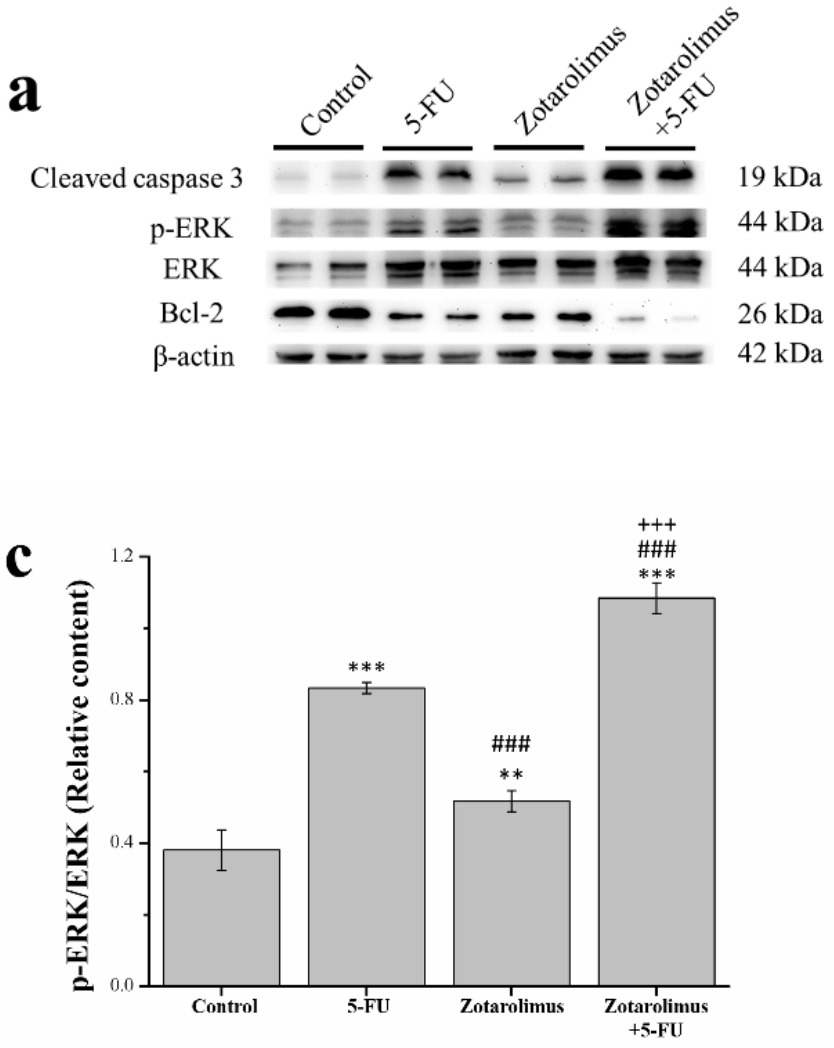
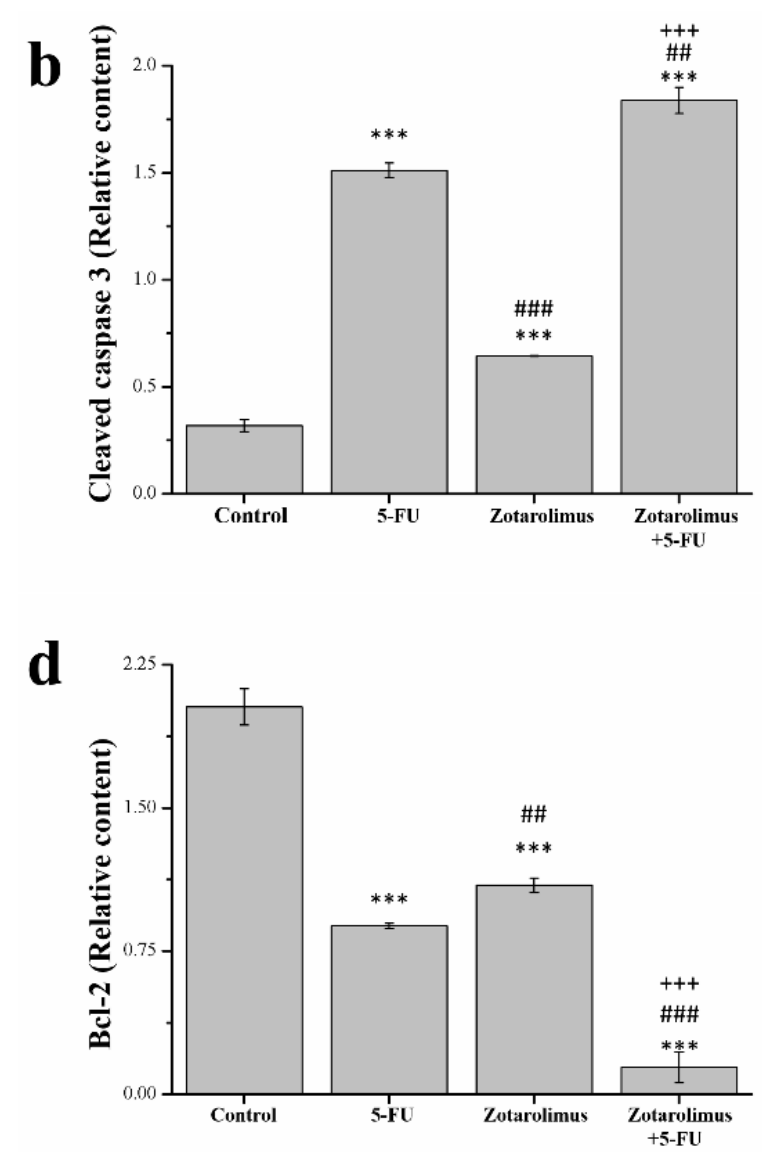

Figure 3. Analysis of apoptosis-related proteins including (a) a representative western blot showing the levels of apoptosisrelated proteins extracted from the tumors; (b) cleaved caspase 3 expression; (c) ERK phosphorylation; and (d) Bcl-2 expression in the A549 tumor masses taken from BALB/cByJNarl control mice and mice given different treatments: 5-FU (100 mg/kg/week), zotarolimus (2 mg/kg/day), and zotarolimus (2 mg/kg/day) combined with 5-FU (100 mg/kg/week). All data are presented as mean \pm standard deviation, $n=7$ per group. ${ }^{* *} p<0.01$ and ${ }^{* *} p<0.001$ compared with the control group. ${ }^{\# \#} p<0.01$ and ${ }^{\# \#} p<0.001$ compared with the 5-FU-treated group. ${ }^{+++} p<0.001$ compared with the zotarolimus-treated group.

\subsection{Zotarolimus Inhibits Production of Cytokines}

Resisting cancer-linked inflammation can delay the disease's progression. The histopathology, observed using immunohistochemistry, revealed levels of inflammatory cytokines including IL-1 $\beta$ (Figure 4a) and TNF- $\alpha$ (Figure $4 \mathrm{~b}$ ). After quantification, in comparison with the control group, the expression of IL-1 $\beta$ and TNF- $\alpha$ were lower in mice treated with 5-FU (by $46.0 \%$ and $44.7 \%$ ), zotarolimus (27.8\% and $18.5 \%$ ), and zotarolimus combined with 5-FU (89.4\% and 81.1\%) (Figure $4 \mathrm{~d}$ ). However, the activity of IL- $1 \beta$ and TNF- $\alpha$ was 1.3 $(p<0.01)$ and $1.5(p<0.001)$ times higher in the zotarolimus group than in the 5-FU group. Moreover, IL-1 $\beta$ and TNF- $\alpha$ expression were the lowest in mice treated with zotarolimus combined with 5-FU. This combination treatment resulted in lower expression than in mice treated with zotarolimus alone (by $85.3 \%$ for IL- $1 \beta$ and $76.8 \%$ for TNF- $\alpha$ ) or 5 -FU alone (by $80.3 \%$ for IL- $1 \beta$ and $65.8 \%$ for TNF- $\alpha$ ). Thus, the expression of IL- $1 \beta$ and TNF- $\alpha$ in mice treated with zotarolimus combined with 5-FU could be largely suppressed in lung adenocarcinoma. 
a

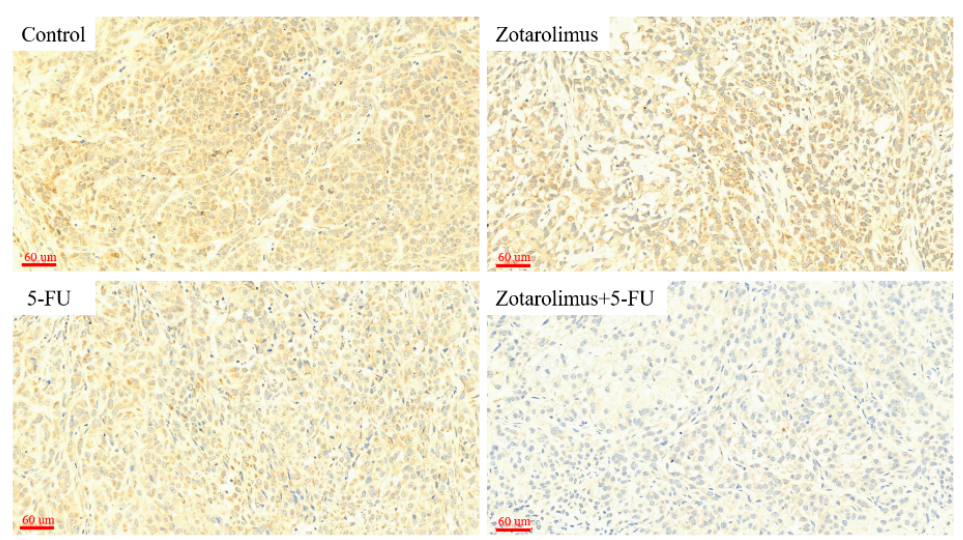

b

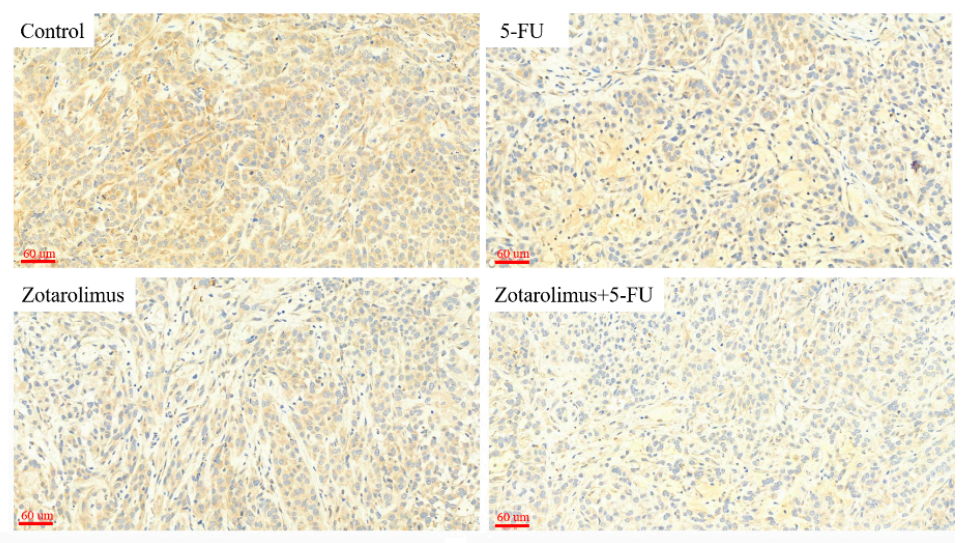

c
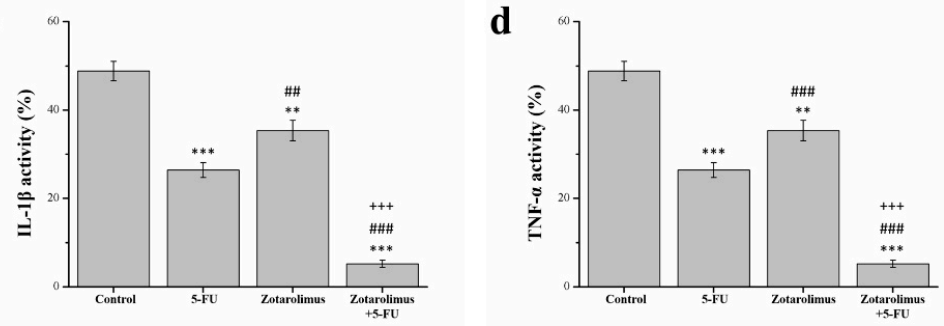

e
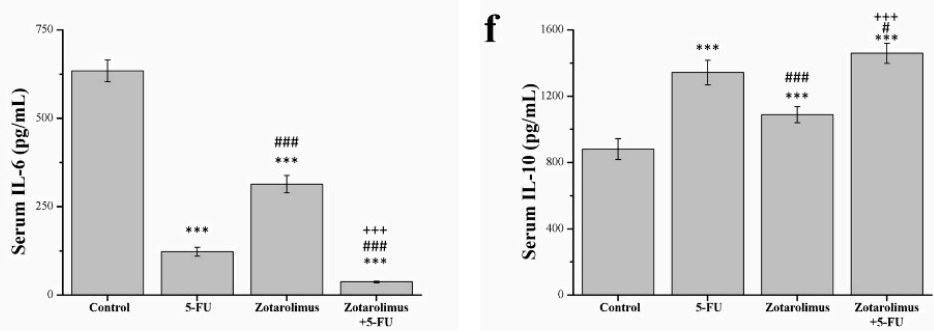

Figure 4. Immunohistochemical expression of (a) IL-1 $\beta$ and (b) TNF- $\alpha$ in A549 tumors from BALB/cByJNarl mice and the comparative immunohistochemical expressions of (c) IL-1 $\beta$ and (d) TNF- $\alpha$; as well as (e) IL-6 and (f) IL-10 levels in serum. All experiments were conducted on the A549 tumor masses from BALB/cByJNarl mice. Findings are reported for the control group and treatments: 5-FU (100 mg/kg/week), zotarolimus ( $2 \mathrm{mg} / \mathrm{kg} /$ day), and zotarolimus ( $2 \mathrm{mg} / \mathrm{kg} /$ day $)$ combined with 5-FU (100 mg/kg/week). All data are presented as mean \pm standard deviation, $n=7$ per group. ${ }^{* *} p<0.01$ and ${ }^{* * *} p<0.001$ compared with the control group. ${ }^{\#} p<0.05,{ }^{\# \#} p<0.01$, and \#\#\# $p<0.001$ compared with the 5-FU group. ${ }^{+++} p<0.001$ compared with the zotarolimus group. Scale bars $=60 \mu \mathrm{m}$. 
In addition, we examined the levels of the inflammatory cytokine IL- 6 and the antiinflammatory cytokine IL-10 in serum using an enzyme-linked immunosorbent assay (ELISA). The expression trend for IL- 6 was similar to those of IL- $1 \beta$ and TNF- $\alpha$. The levels of IL-6 in groups treated with 5-FU, zotarolimus, and zotarolimus combined with 5-FU, respectively, were $80.6 \%, 50.6 \%$, and $94.2 \%$ lower than that of the control group (Figure 4e). However, the IL- 6 levels in mice treated with zotarolimus were 2.6 times higher than those in mice treated with 5-FU. The level of IL-10 in zotarolimus-treated mice was $19.0 \%$ lower than that of IL-10 in 5-FU-treated mice (Figure 4f). Notedly, the decrease in the expression of IL-6 due to zotarolimus combined with 5-FU was $69.6 \%$ and $88.1 \%$ greater than the decline shown by 5 -FU or zotarolimus treatments alone. The level of IL-10 in mice treated with zotarolimus combined with 5-FU was the highest (by 108.7\% for the 5-FU group and $134.1 \%$ for the zotarolimus group). Thus, a reduced expression of IL-1 $\beta$, TNF- $\alpha$, and IL-6 and an enhanced expression of IL-10 were observed in lung adenocarcinoma in mice treated with zotarolimus combined with 5-FU.

\subsection{Zotarolimus Inhibits Inflammation-Related Factors}

Inflammation is closely linked to cancer, and its reduction or elimination may lead to more effective cancer prevention and therapy strategies [33]. Using a western blot, we determined that the cyclooxygenase-2 (COX-2) expression was lower in the groups treated with 5 -FU $(p<0.001)$, zotarolimus $(p<0.001)$, and zotarolimus combined with 5-FU $(p<0.001)$ than in the control group (Figure 5a). Zotarolimus- and 5-FU-treated mice reported a significantly reduced expression of COX-2 compared to control mice. However, the expression of COX-2 was higher in zotarolimus-treated mice $(p<0.001)$ than that in the 5-FU-treated mice (Figure 5b). The treatment with zotarolimus combined with 5-FU resulted in the lowest COX-2 expression. The stimulation of cells with inflammatory cytokines results in the degradation of I $\mathrm{K} B$ kinase $(\mathrm{I} \kappa \mathrm{B} \alpha)$, which inhibits nuclear factor $\kappa \mathrm{B}$ (NF-kB). This leads to the accumulation of NF- $\mathrm{kB}$ and regulation of the specific gene expression [34]. We detected the expression of NF- $\mathrm{KB}$ and I $\mathrm{KB} \alpha \mathrm{mRNA}$ and indicated that NF- $\mathrm{kB}$ was significantly lower in groups treated with 5-FU $(p<0.001)$, zotarolimus $(p<0.001)$, and zotarolimus combined with 5-FU $(p<0.001)$ than in the control group. Further, the inhibitory effect on NF- $k \mathrm{~B}$ expression in zotarolimus-treated mice $(p<0.01)$ was higher than that in 5-FU-treated mice (Figure $5 \mathrm{c}$ ). Zotarolimus combined with 5-FU largely reduced the expression of NF- $\mathrm{kB}$ in all groups. As expected, mice treated with 5-FU $(p<0.001)$, zotarolimus $(p<0.001)$, and zotarolimus combined with 5-FU $(p<0.001)$ reported a higher expression of IкB $\alpha$ than the control mice (Figure $5 \mathrm{~d}$ ). However, the expression of IKB $\alpha$ was lower $(p<0.05)$ in the zotarolimus group than in the 5-FU group. Zotarolimus combined with 5-FU increased the expression of I $\mathrm{B} \alpha \mathrm{mRNA}$. Our results showed that zotarolimus inhibited inflammation-related factors and inflammatory responses. However, zotarolimus-treated mice did not show a greater reduction in inflammation-related factors than 5-FU-treated mice. Nevertheless, the co-effect of zotarolimus and 5-FU achieved a greater inhibition of the inflammatory reactions in mice.

\subsection{Zotarolimus Inhibits Metastasis-Related Factors}

Cancer metastasis is the major cause of cancer morbidity and mortality and accounts for approximately $90 \%$ of cancer deaths [35]. For observations, we selected metastasisrelated factors including TGF- $\beta$, CD44, EGFR, and VEGF. We used IHC to detect the expression of TGF- $\beta$ and CD44 (Figure $6 a, b$ ). The pathological sections indicated lower TGF- $\beta$ and CD44 expression in the groups treated with 5-FU (TGF- $\beta: p<0.001$; CD44: $p<0.001$ ), zotarolimus (TGF- $\beta: p<0.001$; CD44: $p<0.001$ ), and zotarolimus combined with 5-FU (TGF- $\beta: p<0.001$; CD44: $p<0.001$ ) than in the control group. Quantification of the results showed that, compared with the control group, the levels of TGF- $\beta$ expression in those treated with 5-FU, zotarolimus, and zotarolimus combined with 5-FU were lower by $63.1 \%, 29.2 \%$, and $81.0 \%$, respectively (Figure 6c). Further, the levels of CD44 expression in the groups treated with 5-FU, zotarolimus, and zotarolimus combined with 5-FU were 
lower by $64.1 \%, 31.1 \%$, and $73.9 \%$, respectively (Figure $6 \mathrm{~d}$ ). However, the TGF- $\beta$ and CD44 expression in the zotarolimus group were both 1.9 times higher than those in the 5-FU group. The group treated with zotarolimus combined with 5-FU showed significantly reduced TGF- $\beta$ and CD44 expression in comparison with those reported for the 5-FU group and zotarolimus group (by $48.4 \%$ and $73.1 \%$ for TGF- $\beta$ and by $27.4 \%$ and $61.6 \%$ for CD44). The western blotting revealed similar trends for VEGF and EGFR (Figure 6e). The expression of EGFR and VEGF showed a significantly greater decrease in the groups treated with 5-FU (EGFR: $p<0.001$; VEGF: $p<0.01$ ), zotarolimus (EGFR: $p<0.01$; VEGF: $p<0.01$ ), and zotarolimus combined with 5-FU (EGFR: $p<0.001$; VEGF: $p<0.001$ ) when compared with the control group (Figure 6f,g). The EGFR expression in zotarolimus-treated mice $(p<0.01)$ was higher than that in 5 -FU-treated mice; however, the VEGF expression in the zotarolimus group was not significant in comparison with the 5-FU group. Mice treated with zotarolimus combined with 5-FU showed the lowest expression of EGFR and VEGF. Thus, zotarolimus could inhibit metastasis-related factors, and zotarolimus combined with 5-FU had the greatest suppressing effect on metastasis.
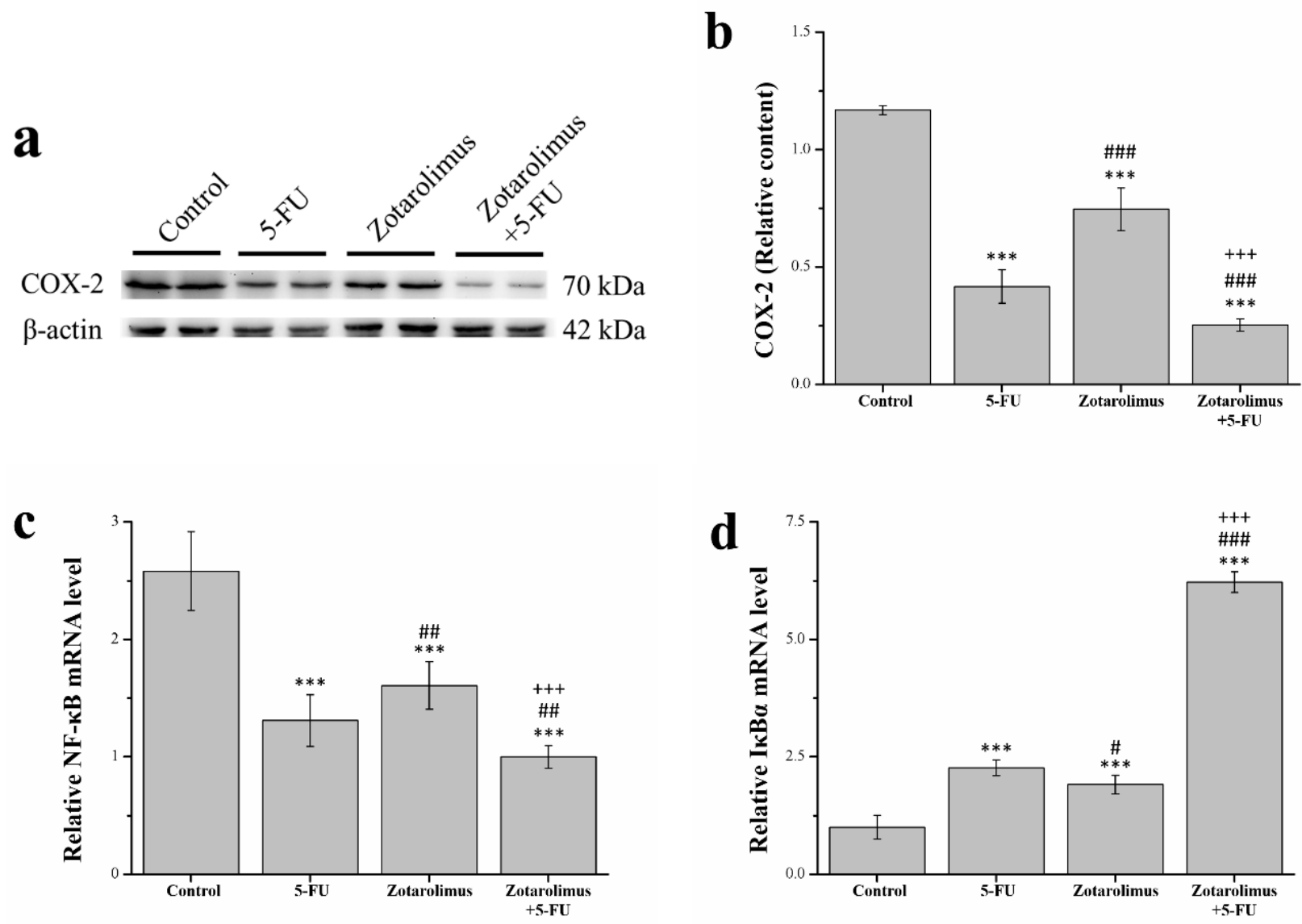

Figure 5. Western blot analysis of (a) inflammation-related factors extracted from the tumors in a representative blot; and (b) COX-2 expression in the A549 tumor mass from BALB/cByJNarl mice subjected to various treatments. The relative mRNA expression levels of (c) NF- $\kappa B$ and (d) I $\mathrm{kB} \alpha$ were estimated using quantitative PCR. All experiments were conducted on A549 tumor masses from BALB/cByJNarl mice in the control group and mice given different treatments: 5-FU (100 mg/kg/week), zotarolimus (2 mg/kg/day), and zotarolimus (2 mg/kg/day) combined with 5-FU (100 mg/kg/week). All data are presented as mean \pm standard deviation, $n=7$ per group. ${ }^{* * *} p<0.001$ compared with the control group. ${ }^{\#} p<0.05,{ }^{\# \#} p<0.01$, and ${ }^{\# \#} p<0.001$ compared with the 5-FU group. ${ }^{+++} p<0.001$ compared with the zotarolimus group. 
a

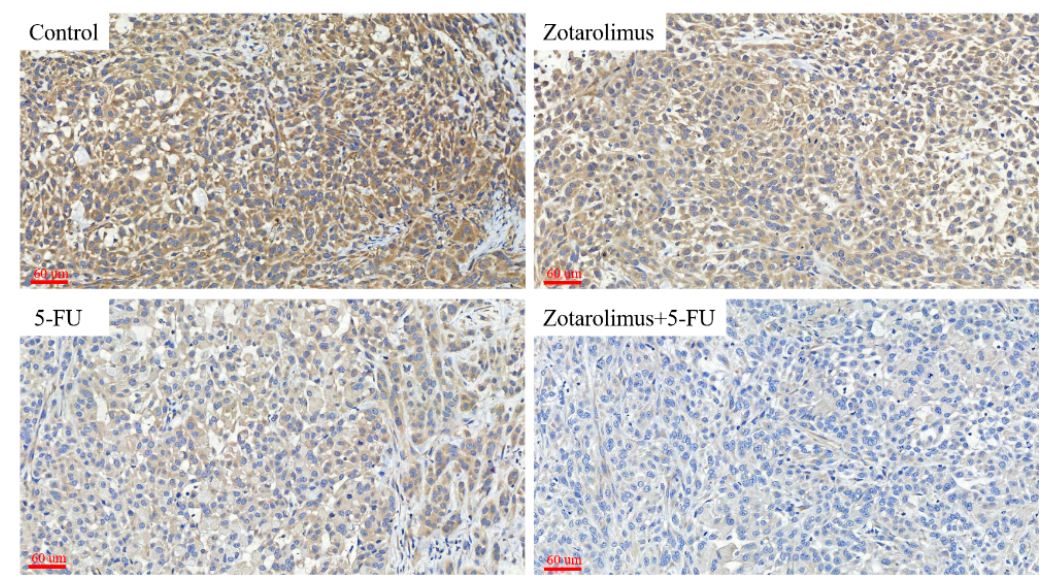

b

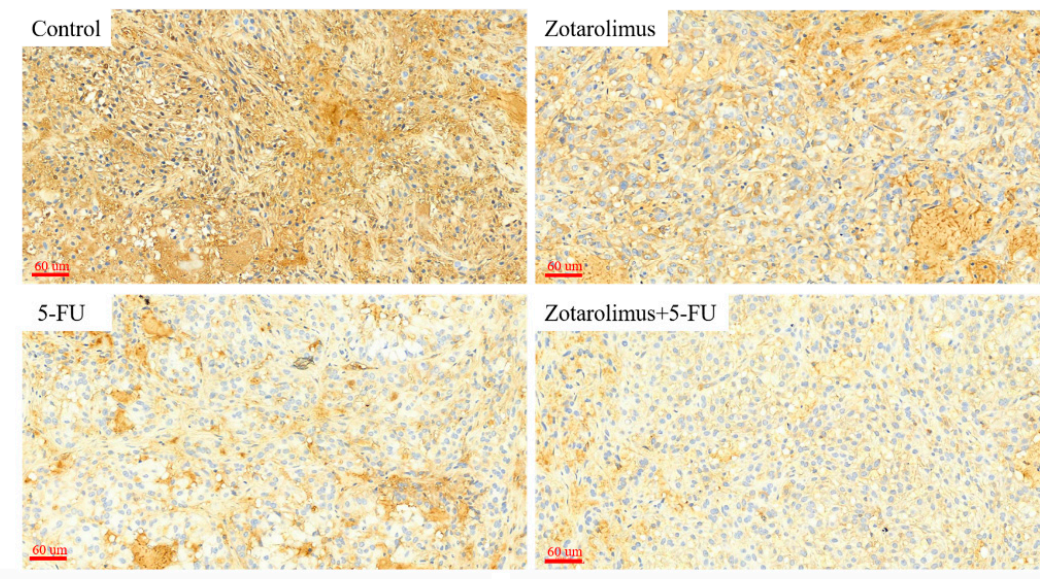

c

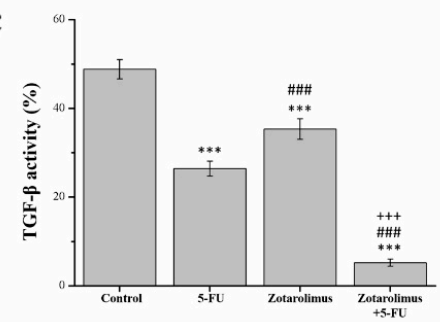

d

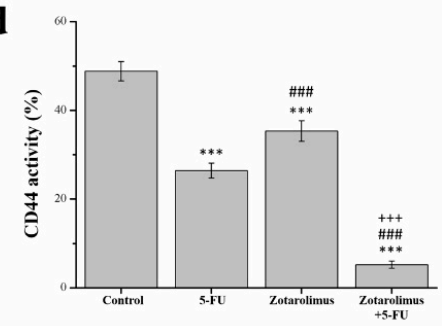

$\mathbf{e}$

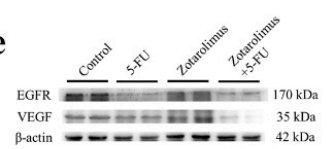

f

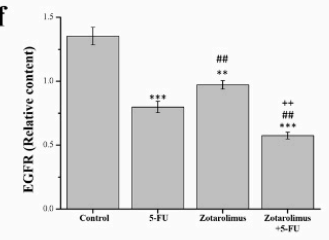

g

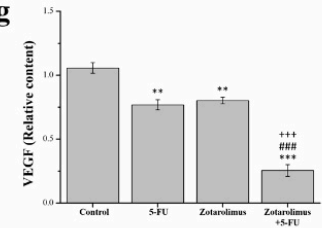

Figure 6. Immunohistochemical expression of (a) TGF- $\beta$ and (b) CD44 and a comparison of the expression levels of (c) TGF- $\beta$ and (d) CD44. Western blot analysis (e) showing the expression of metastasis-related factors extracted from tumors in a representative blot. Expression of (f) VEGF and (g) EGFR in the A549 tumor masses from BALB/cByJNarl in control mice and mice given different treatments, including 5-FU (100 mg/ kg/week), zotarolimus ( $2 \mathrm{mg} / \mathrm{kg} /$ day), and zotarolimus ( $2 \mathrm{mg} / \mathrm{kg} /$ day) combined with 5-FU (100 mg/kg/week). All data are presented as mean \pm standard deviation, $n=7$ per group. ${ }^{* *} p<0.01$ and ${ }^{* * *} p<0.001$ compared with the control group. ${ }^{* \#} p<0.01$ and ${ }^{\# \#} p<0.001$ compared with the 5-FU-treated group. ${ }^{++} p<0.01$ and ${ }^{+++} p<0.001$ compared with the zotarolimus-treated group. Scale bars $=60 \mu \mathrm{m}$. 


\section{Discussion}

This study examined the impact of zotarolimus alone and zotarolimus combined with 5-FU on the development of A549 tumors in nude mice. Nude mice constitute an effective model for evaluating the ectopic xenotransplantation of human carcinoma cells for drug or chemical treatment $[7,36,37]$. Tumor cell-bearing nude mice could be favorable for tumor growth because such mice have no thymus to produce T cells [38]. A preliminary experiment showed that zotarolimus $(1 \mathrm{mg} / \mathrm{kg} /$ day $)$ significantly inhibit the growth of a lung adenocarcinoma tumor formed from A549 cells, and zotarolimus combined with 5-FU provided a similar inhibitory effect on tumor weight as 5-FU alone (Figure A1). Therefore, we decided to use $2 \mathrm{mg} / \mathrm{kg} /$ day of zotarolimus. The results indicated zotarolimus inhibited tumor size and weight, as was observed for the 5-FU-treated mice. However, the inhibitory effect of zotarolimus alone was not greater than that of 5-FU alone. Zotarolimus combined with 5-FU achieved the highest inhibitory effect when compared with groups treated with 5-FU or zotarolimus alone. In terms of apoptosis, zotarolimus combined with 5-FU increased the expression of cleaved caspase 3 and ERK phosphorylation and decreased Bcl-2 expression. This indicated that zotarolimus combined with 5-FU could be the most effective in promoting apoptosis during lung adenocarcinoma treatment. From the viewpoint of inflammation, both groups treated with zotarolimus and zotarolimus combined with 5-FU reduced the production of inflammatory factors including IL-1 $\beta$, TNF- $\alpha$, IL-6, COX-2, and NF- $k$ B. Finally, zotarolimus inhibited metastasis-related factors including TGF- $\beta$, CD44, VEGF, and EGFR. Accordingly, the synergistic effect of zotarolimus and 5-FU largely inhibited the expression of inflammatory and tumor metastasis-related factors.

The mTOR pathway is a major downstream signaling pathway activated through multiple biological functions involved in cell cycle regulation and performs key functions in autophagic regulation $[39,40]$. Signals from aberrantly activated mTOR not only promote the growth and metastasis of tumor cells but also help the cells invade healthy tissues [41]. Many drugs inhibiting the mTOR pathway are used in cancer therapy, including temsirolimus, everolimus, and ridaforolimus [42,43]. A study on the effectiveness of temsirolimus demonstrated that the drug inhibits the proliferation of cultured NSCLC cells at a low concentration and prolongs the survival of mice with disseminated pleural NSCLC tumors [44]. Everolimus treatment markedly delayed tumor development and inhibited the expression of VEGF in tumor-derived cell lines from ovarian cancers. In addition, everolimus effectively inhibits the phosphorylation of p70S6K and upregulates the phosphorylation of protein-serine-threonine kinase (AKT) [45]. A study also showed that ridaforolimus inhibits mTOR activity, and thus, tumor cell proliferation and VEGF production [46]. In sum, these studies have highlighted that mTOR pathway inhibitors are effective in cancer treatment, which has furthered research interest in their nature and application. Our results showed that zotarolimus inhibited the growth of A549 cells, and thus, it could be suggested in clinical administered to inhibit the proliferation of lung adenocarcinoma.

Several studies have shown that combination chemotherapy with an anti-cancer drug and a cell-signal inhibitor achieves a better response rate than either used alone. Everolimus, for example, in combination with a high dose of cyclophosphamide showed synergistic antitumor activity in vivo, as observed in the treatment of gastric cancer [47]. Furthermore, addition of rapamycin diminished the residual activity of mTORC1 and significantly intensified the cytotoxicity of cisplatin in the gastric carcinoma cells producing alpha-fetoprotein (AFP) to be resistant to cisplatin [48]. Therefore, this study investigated the inhibitory and synergistic impact of zotarolimus combined with 5-FU on A549 lung adenocarcinoma cells implanted in mice. Our results revealed that zotarolimus combined with 5-FU had a strong inhibitory effect on tumor cell growth. In addition, zotarolimus alone had inhibitory effects on A549 cells. The synergistic effect of zotarolimus and 5-FU further strengthened the inhibitory potency on tumor growth.

Next, we explored the apoptotic fraction, an important indicator for tumors. Cancer cells can evade apoptosis and continually replicate despite abnormalities. Chemotherapy 
drugs and radiation force the apoptosis of cancer cells, wherein death signals are triggering by DNA damage or cellular distress [49]. The findings related to TUNEL and DAPI for mice treated with zotarolimus and zotarolimus combined with 5-FU revealed the extent of apoptosis in A549 lung adenocarcinoma cells. Zotarolimus enhanced the apoptosis of lung adenocarcinoma, even without 5-FU. Zotarolimus combined with 5-FU substantially increased the fraction of apoptotic cells. Thus, zotarolimus combined with 5-FU hinders the ability of cancer cells to evade apoptosis, increasing the rate of apoptosis and inhibiting tumor growth. In addition, our Western blots showed higher expression of cleaved caspase 3 and ERK phosphorylation, which are central players in apoptosis, in mice treated with zotarolimus combined with 5-FU. Bcl-2 expression exhibited an opposing trend because tumor cells become dependent on anti-apoptotic Bcl-2 to survive [50]. One study demonstrated that treatment with mTOR kinase inhibitors resulted in elevated expression levels of cleaved caspase 3 proteins and dramatically downregulated Bcl-2 levels when mTOR was downregulated in human laryngocarcinoma and lung cancer [51,52]. Everolimus also significantly decreased the expression of all pro-survival Bcl-2 family proteins, including p-Bcl-2 (Ser70), p-Bcl-2 (Thr56), and Bcl-2 [53]. Moreover, zotarolimus also reduces the expression of S6K1 and mTOR (Figure A2). One downstream pathway of mTOR targets $\mathrm{S} 6 \mathrm{~K}$, a protein which attaches to mitochondrial membranes and can phosphorylate serine 136 in the pro-apoptotic molecule $\mathrm{BAD}$ (Bcl-xL/Bcl-2 associated death promoter) to inactivate it. This phosphorylation interrupts BAD's binding to the mitochondrial death inhibitors Bcl-XL and Bcl-2 [54]. Thus, mTOR can inhibit apoptosis. Accordingly, through the inhibition of the mTOR pathway, the expression of cleaved caspase 3 and ERK phosphorylation showed a significant higher increase in the groups treated with zotarolimus and zotarolimus combined with 5-FU than in the control group. The apoptosis-related results showed a corresponding trend for tumor size in line with our expectations.

There is significant research and clinical data that support the interdependent relationship between inflammation and tumors [55]. Chronic inflammation has been closely associated with tumorigenesis, and several solid tumors maintain an inflammatory immune microenvironment to accelerate tumor progression and metastasis [56]. We observed inflammation factors such as IL- $1 \beta$, TNF- $\alpha$, IL-6, IL-10, COX-2, and NF- $k$ B. IL-1 $\beta$ and TNF- $\alpha$, in particular, show a notable overlap of biological activity in cancer and promote tumor angiogenesis by inducing tumor cells to secrete VEGF via the IкB/TSC1/mTOR pathway [57]. Studies on lung cancer patients have shown a relationship between IL-6 and cancer cachexia and cancer-related fatigue [58]. IL-6 is a pro-tumorigenic cytokine that triggers JAK/STAT3 activation, which promotes tumor cell growth and suppresses tumor cell apoptosis [59]. The anti-inflammatory response is largely controlled by IL-10. Related to the effect of anti-inflammatory responses, the binding of IL-10 to IL-10R activates the IL-10/JAK/STAT3 cascade, where phosphorylated STAT3 homodimers translocate to the nucleus within seconds, indirectly influencing the expression of target genes such as TNF- $\alpha$ and NF- $\mathrm{KB}$ [60]. IL-10 inhibits tumorigenesis by downregulating VEGF, IL-1b, TNF- $\alpha$, IL-6, and MMP-9 [61]. Research has associated IL-10 deficiency with the increased production of pro-inflammatory cytokines, which promote tumor growth in mice [62]. Here, the administration of zotarolimus could reduce the expression of IL- $1 \beta$, TNF- $\alpha$, and IL- 6 and increase serum IL-10 levels. In addition, zotarolimus combined with 5-FU significantly reduced inflammation-related factors and increased anti-inflammation factors. C-reactive protein (CRP) synthesis mainly occurs in response to stimulation by pro-inflammatory cytokines [63]. Elevated levels of CRP have been associated with increased lung cancer risk and tumor progression [64]. We found that, in comparison with the control mice, mice treated with 5-FU, zotarolimus, or zotarolimus combined with 5-FU reported reduced serum CRP (Figure A3). The highest level of serum CRP was exhibited in the group administered with zotarolimus combined with 5-FU, which was associated with the highest inhibition rate of tumor growth. Thus, zotarolimus can retard tumor growth by attenuating inflammatory cytokine expression and elevating anti-inflammation mediators. 
The TNF- $\alpha$ stimulation activates IкB, a major downstream kinase in the TNF- $\alpha$ signaling pathway, where it phosphorylates I $\mathrm{B} \alpha$ and, subsequently, triggers its degradation through the ubiquitin-proteasome proteolytic system [65]. In the absence of $I \kappa B \alpha$, which is necessary to retain NF- $\mathrm{kB}$ in the cytosol, NF- $\mathrm{kB}$ is liberated and translocates into the nucleus and activates other target genes, such as genes encoding cytokines and those involved in angiogenesis, proliferation, and metastasis [66]. Various NF- $\mathrm{kB}$ target genes inhibit apoptosis and mediate inflammation, and thus, NF- $\mathrm{KB}$ functions as a tumor promoter in inflammation-associated cancer [67]. In malignant cells, NF- $k B$ inhibition would increase susceptibility to apoptosis-inducing agents [66]. Accordingly, NF- $\mathrm{kB}$ and $\mathrm{I} \kappa \mathrm{B} \alpha$ play a role in various immune processes and inflammatory responses. We also detected their mRNA expression in A549 lung adenocarcinoma. Zotarolimus and zotarolimus combined with 5 -FU increased the expression of I $\kappa \mathrm{B} \alpha$ and inhibited NF- $\mathrm{kB}$, and subsequently, prevented inflammatory reactions. This result showed a reduction in the NF- $\mathrm{KB}$ transcription factor family, which inhibited the central mediator of the inflammatory process and enhances a key participant in the immune response to cancer [68]. Thus, zotarolimus could affect the development of tumors by regulating the critical link between inflammation and cancer. Proliferation of cell nuclear antigen (PCNA) is also an indicator of cell proliferation activity, and its expression is correlated with the development of cancer and positively correlated with COX-2 [69]. Studies have shown that the elevated levels of COX-2 have implications in angiogenesis, tumor invasion, resistance to apoptosis, and suppression of antitumor immunity [70]. Similar to PCNA, the expression of Ki67 is strongly associated with tumor cell proliferation and growth and is widely used in routine pathological investigation as a proliferation marker [71]. Our study indicated that zotarolimus alone and zotarolimus combined with 5-FU significantly decreased the expression of PCNA (Figure A4) and Ki67 (Figure A5) in lung adenocarcinoma. Thus, zotarolimus inhibits the expression of growth and anti-apoptotic factors in lung adenocarcinoma cell by downregulating inflammation and tumorigenesis during the stages of tumor promotion and progression.

Another key indicator in oncology research is metastasis. Studies have shown that TGF- $\beta 1$ stimulates the proliferation and migration of highly transformed tumor cells, causing metastasis and tumor progression [72]. In addition, TGF- $\beta$ decreases the cytotoxicity of anticancer drugs [73]. CD44 regulates the phosphoinositide-3-kinase (PI3K)/AKT/mTOR signaling pathway and promotes cancer cell migration [74]. CD44-induced epithelialmesenchymal transition (EMT), however, is strongly correlated with cancer metastasis and is regulated by TGF- $\beta 1$, and the anti-tumor effect could inhibit the expression of both CD44 and TGF- $\beta$ [75]. Our results showed that zotarolimus and zotarolimus combined with 5-FU largely reduced the presence of TGF- $\beta$ and CD44 in tumor immunostaining. Therefore, zotarolimus and zotarolimus combined with 5-FU reduced the metastasis ability of the A549 lung adenocarcinoma cells. Accordingly, it is likely that reducing the expression of TGF- $\beta$ rendered the effect of drug therapy more prominent, causing inhibition on tumor metastasis, which is in line with the abovementioned reference [73]. As for other metastasis-related factors, VEGF is a potent promoter of angiogenesis, and the overexpression of VEGF is associated with the progression and metastasis of tumor progression [76]. A study on the effect of mTOR on VEGF showed that everolimus reduced human VEGF secretion by $20-45 \%$ in wild type and resistant cancer cell lines including GEO and GEO-GR (gefitinib resistant) colon cancer [77]. A similar report indicated that the inhibition of tumors by rapamycin is based on antiangiogenic activity, which is correlated with the impaired production of VEGF and the blockage of vascular endothelial cell stimulation induced by VEGF [78]. EGFR is a major signal transducer of mitogens in cancer pathogenesis and the progression, upstream, of mTOR and is an important target in anticancer therapy [79]. VEGF and EGFR signaling synergize to promote epidermal tumor growth [80]. In addition, zinc finger E-box-binding homeobox 1 (ZEB1) acts as an oncogene in invasive and metastatic lung cancer cells, in which the ZEB1-induced epithelial-mesenchymal transition promotes the loss of epithelial cell polarity and adhesion; induces cytoskeleton remodeling; and drives growth, migration, invasion, and metastasis [81,82]. Zotarolimus alone and zotarolimus combined with 
5-FU reduced the metastatic ability of the A549 lung adenocarcinoma cells, which may be attributed to the decreased mRNA expression of ZEB1 (Figure A6). Our results indicate zotarolimus has an anti-tumor effect, and when zotarolimus is combined with 5-FU, this effect on suppressing tumor metastasis is strengthened. Thus, zotarolimus combined with 5-FU significantly suppressed tumors by reducing VEGF and EGFR expression.

An increasing number of lung cancers are becoming resistant to chemotherapy drugs and forming resistant cell lines. Cisplatin, for example, is a common constituent of first-line treatment after surgery $[83,84]$. However, many patients undergoing lung cancer treatment have shown resistance to cisplatin on the basis of several alterations or defects in signaling pathways in response to the DNA damage caused by cisplatin [85]. Recently, a combination of BEZ235, a novel dual PI3K/mTOR inhibitor, and cisplatin was reported to provide synergistic antitumor effects in cisplatin-resistant A549 cells, as reflected by reduced proliferation, increased apoptosis, and migration suppression. Moreover, tumor development and metastasis are closely related to the structure and function of the tumor microenvironment (TME) [86]. Tumor-infiltrating lymphocytes (TILs) are reportedly involved in lung cancer development, prognosis, and immunotherapy efficacy in the TME [87]. During the IHC staining of tumor tissues with CD45 (TIL-specific marker), the percentages of CD45 activity in the 5-FU, zotarolimus, and zotarolimus combined with 5-FU groups were 9.5-fold, 8.6-fold, and 10-fold higher than that in the control group, respectively (Figure A7) [88]. These data clearly indicate that zotarolimus plays a key role in the inhibition of lung adenocarcinoma. In addition, the mechanism mediating these effects may be associated with the inhibition of PI3K/Akt/mTOR signaling [89]. The anti-tumor effects of zotarolimus alone on tumor growth were not superior to those of 5-FU in the A549 human lung adenocarcinoma epithelial cells. However, zotarolimus combined with 5-FU exhibited excellent inhibition of A549 cell growth in terms of apoptosis, inflammation, and metastasis.

\section{Materials and Methods}

\subsection{Animals and Cell Lines}

For the purpose of this research, six-week-old male BALB/cByJNarl mice were purchased from the National Laboratory Animal Breeding and Research Center (Taipei, Taiwan). Each cage housed two mice, and sterilized food and water were provided. The mice were kept at a constant temperature $\left(22 \pm 2{ }^{\circ} \mathrm{C}\right)$ and relative humidity $(55 \pm 5 \%)$ under a 12:12 h light:dark cycle. The animal use protocol was reviewed and approved by the Institutional Animal Care and Use Committee (IACUC) at the National Chiayi University (IACUC Approval No. 108028). All procedures were in line with the Guidelines for the Care and Use of Laboratory Animals by Taiwan's Ministry of Health and Welfare.

The A549 human lung carcinoma cell line was purchased from the Bioresource Collection and Research Center (Hsinchu, Taiwan). The cells were grown in Dulbecco's modified Eagle's medium and supplemented with $5 \%$ fetal bovine serum, $50 \mathrm{IU} / \mathrm{mL}$ of penicillin, and $50 \mathrm{mg} / \mathrm{mL}$ of streptomycin (Gibco Laboratories, Grand Island, NY, USA) in a humidified atmosphere of $95 \%$ air and $5 \% \mathrm{CO}_{2}$ at $37^{\circ} \mathrm{C}$. The cells were routinely passaged by removing the medium and overlaying the cell monolayer with $0.25 \%$ trypsin and $0.1 \%$ EDTA.

\subsection{Tumor Inoculation and Treatment}

The experiment was designed such that the treatment began after the injection of A549 cells formed a tumor mass detectable on day 7. Briefly, once the mice were anesthetized using an intraperitoneal injection of Zoletil ${ }^{\circledR}$ (Virbac Taiwan, Taipei, Taiwan), a subcutaneously injection in the posterior leg delivered $100 \mu \mathrm{L}$ of a cell suspension containing $10^{6}$ viable A549 cells. The mice did not show an apparent mass on day 1 . The development of tumor lesions was examined on day 7. The mice that showed a distinct tumor $4-5 \mathrm{~mm}$ in diameter [90] were divided into four groups. Starting on day 7, all mice that had developed apparent tumors were randomly divided into four groups (8 per group). Group I, the control group, was given saline on a daily basis through an intraperitoneal injection. 
Group II received intraperitoneal injections of 5-FU (100 mg/kg/week) (Sigma; St. Louis, MO, USA). Group III received intraperitoneal injections of zotarolimus (2 mg/ $\mathrm{kg} /$ day $)$ (MedChemExpress, Monmouth Junction, NJ, USA). Group IV was given intraperitoneal injections of zotarolimus $(2 \mathrm{mg} / \mathrm{kg} /$ day $)$ and $5-\mathrm{FU}(100 \mathrm{mg} / \mathrm{kg} /$ week $)$. We determined the 5-FU dosage on the basis of mouse studies on the role of 5-FU in the apoptosis, invasion, metastasis, angiogenesis, and growth signaling mechanisms of cancer cells [91-93]. In addition, the dosage was lower than the threshold at $150 \mathrm{mg} / \mathrm{kg}$ /week; the increased efficacy correlated with an increase in the lethal toxicity of 5-FU [94]. Alternatively, the dosage of zotarolimus was based on that generally administered for everolimus [95]. Tumor growth was monitored every seven days by measuring the largest and smallest diameters. Tumor volume was calculated using the following formula: $\mathrm{V}=0.5 \times \mathrm{a} \times \mathrm{b}^{2}$, where $\mathrm{a}$ is the largest diameter and $b$ is the smallest.

\subsection{Clinical Observations and Histopathological Analysis}

The mice were observed on a daily basis for clinical signs and sacrificed after one month. Body weight was measured every three days. Blood was collected to evaluate hematology under anesthesia at the end of the treatment period. Tumor specimens were divided into two groups. One group was treated with $10 \%$ formalin and embedded in paraffin. The specimens were assessed by hematoxylin and eosin staining; terminal deoxyribonucleotidyl transferase (TdT)-mediated biotin-16-dUTP nick-end labeling (TUNEL assay; APO-BrdU ${ }^{\mathrm{TM}}$ TUNEL Assay Kit, BD Pharmingen Inc., San Diego, CA, USA); and immunohistochemistry (IHC) for IL-1 $\beta$, TNF- $\alpha$, TGF- $\beta$, and CD44. Additional IHC staining for IL-1 $\beta$, TNF- $\alpha$, TGF- $\beta$, and CD44 in the tumor was assessed using primary antibodies against IL- $1 \beta$, TNF- $\alpha$, TGF- $\beta$, and CD44 (Merck, Billerica, MA, USA). Protein expression was measured through IHC using the TAlink mouse/rabbit polymer detection system by BioTnA (Kaohsiung, Taiwan). A Moticam 2300 (Motic Instruments, Richmond, BC, Canada), a high-resolution digital microscope equipped with Motic Images Plus (version 2.0), was used to capture and analyze the images. The other group was preserved in a freezer at $-80^{\circ} \mathrm{C}$. Western blotting was applied to examine cleaved caspase 3, ERK, Bcl-2, COX-2, VEGF, and EGFR.

\subsection{Measurement of Serum Levels of IL-6 and IL-10}

The blood samples were used to measure serum levels of IL-6 and IL-10 using mice commercial kits (ab213749 and ab100697; Abcam, Cambridge, MA, USA) following the manufacturer instructions. Samples of $50 \mu \mathrm{L}$ were added to each well of the 96 -well antibody-coated plates and then incubated for $2 \mathrm{~h}$ at room temperature. The detector antibody solution $(50 \mu \mathrm{L})$ was loaded into each well and the plates were incubated for $1 \mathrm{~h}$ at room temperature. Next, $50 \mu \mathrm{L}$ of the HRP-Streptavidin solution (ab210901, Abcam) was added, and the plates were incubated for another $1 \mathrm{~h}$. Then, $100 \mu \mathrm{L}$ of TMB substrate was added to each well and the plates were incubated for $10 \mathrm{~min}$ in the dark. The reaction was stopped with the addition of $100 \mu \mathrm{L}$ stop solution. A wavelength $450 \mathrm{~nm}$ was used to read the absorbance and the results are expressed in $\mathrm{pg} / \mathrm{mL}$.

\subsection{RNA Extraction and Real-Time Quantitative PCR}

TRI Reagent (Sigma-Aldrich) was used to extract total RNA from the tumor tissues. We assessed RNA concentration on the basis of absorbance at 260-280 nm and 230-260 nm on a Qubit fluorometer (Invitrogen, Carlsbad, CA, USA). The RNA (1 $\mu \mathrm{g})$ was reverse transcribed into cDNA using an iScript cDNA synthesis kit (Bio-Rad, Hercules, CA, USA) following the manufacturer's protocol. Real-time PCR was performed using the cDNA and iTaq universal SYBR Green supermix (Bio-Rad) following the manufacturer's instructions. NF- $\mathrm{kB}$ and I $\mathrm{KB} \alpha \mathrm{mRNA}$ expression levels were determined using the CFX Connect Real-Time PCR Detection System (Bio-Rad). The settings for the PCR were as follows: 40 cycles of $95{ }^{\circ} \mathrm{C}$ for $30 \mathrm{~s} ; 95^{\circ} \mathrm{C}$ for $15 \mathrm{~s}$, and $60^{\circ} \mathrm{C}$ for $30 \mathrm{~s}$; and a final $5 \mathrm{~min}$ at $72{ }^{\circ} \mathrm{C}$. The NF- $\mathrm{KB}, \mathrm{I} \kappa \mathrm{B} \alpha$, and $\beta$-actin sequence primers employed 
in this study were NF- $\mathrm{kB}$ forward, $5^{\prime}$-ATGGCTTCTATGAGGCTGAG- ${ }^{\prime}$, and reverse, $5^{\prime}$ GTTGTTGTTGGTCTGGATGC- $3^{\prime}$; I I $B-\alpha$ forward, $5^{\prime}$-GCCCTTGTCCCTGTCCCTA- $3^{\prime}$, and reverse, $5^{\prime}$-GCAGAGTATTTCCCTTTGGTTTGA- ${ }^{\prime}$; and $\beta$ actin forward, $5^{\prime}$-ACTGGAACGGTGAAGGTGACA- $3^{\prime}$, and reverse, $5^{\prime}$-ATGGCAAGGGACTTCCTGTAAC- ${ }^{\prime}[96,97]$. The expression levels for each target gene were calculated relative to the $\beta$-actin levels and expressed using the $2^{-\Delta \Delta \mathrm{Ct}}$ method.

\subsection{Western Blotting}

Following the experiment, mice were euthanized with an overdose of anesthetic combined with carbon dioxide. Tumors were quickly obtained from the mice, then coarsely minced and homogenized. Western blotting was then performed as previously described [98-100]. For detection, we used antibodies against $\beta$-actin, Bcl-2, and COX-2 from Sigma-Aldrich Inc. (St. Louis, MO, USA); VEGF and EGFR were also purchased from Sigma-Aldrich (St. Louis, MO, USA); and cleaved caspase 3, phosphorylated ERK (threonine 202/tyrosine 204), and ERK were from Cell Signaling Technology (Beverly, MA, USA). Enhanced chemiluminescence reagents (Thermo Scientific, Rockford, MA, USA) generated the immunoreactive signals and UVP ChemStudio (Analytik Jena, Upland, CA, USA) was used for signal detection. The quantification of protein expression and phosphorylation was performed using ImageJ software from the National Institutes of Health (NIH; Bethesda, MA, USA).

\subsection{Statistical Analysis}

All results are shown as mean \pm standard deviation. A $t$-test was used to determine if there was a difference between two groups. When more than two groups were analyzed, an ANOVA test using a post hoc Bonferroni correction determined differences between the groups. $p$-values less than $0.05,0.01$, and 0.001 were considered significant, very significant, and extremely significant, respectively.

\section{Conclusions}

In conclusion, this study highlights the potential co-effect of zotarolimus and 5-FU for the treatment of human lung adenocarcinoma. Our findings evidenced that zotarolimus alone inhibits the tumor development of A549 cell in vivo and that combining zotarolimus with a traditional chemotherapy drug such as 5-FU exerts a stronger inhibitory effect. This observation is associated with the inhibition of tumor growth via an apoptotic mechanism in A549 cells where the apoptotic expression of cleaved caspase 3 and ERK phosphorylation is enhanced and the anti-apoptotic expression of $\mathrm{Bcl}-2$ is reduced. Our study also revealed that both zotarolimus alone and the combination of zotarolimus and 5-FU decreased the production of inflammatory cytokines, including IL- $1 \beta$, TNF- $\alpha$, and IL- 6 , and increased the production of the anti-inflammatory cytokine Il-10. This could inhibit tumorigenesis. Antitumor and anti-inflammation treatments are characterized by the decreased accumulation of COX-2 and NF- $\kappa B$ mRNA and an increase in I $\mathrm{B} \alpha$ mRNA. The inhibition of the mTOR signaling pathway in tumors by zotarolimus reduced TGF- $\beta$, CD44, VEGF, and EGFR expression, which could decelerate tumor cell migration and invasion in cancer metastasis. Collectively, the in vivo data revealed the pharmacological effects of zotarolimus, where it was shown effectively to enhance apoptosis, decrease inflammatory processes, and increase cancer metastasis-suppressing mechanisms. This indicates certain benefits for tumor treatment revealed by the xenograft-induced tumor mass and volume in the nude mice. The combination of zotarolimus and 5-FU has a synergistic effect on suppressing tumor growth, although the use of zotarolimus alone also has a similar effect. These results may pave the way for providing more options in cancer treatment and the development of new therapeutic strategies for treating lung adenocarcinoma cancer. 
Author Contributions: C.-F.W. conceived the idea and performed experiments. C.-Y.W., W.-C.Y., C.-F.L., and C.-M.W. assisted in recombinant construction. P.-H.H. and T.-C.L. analyzed the data. C.-Y.K., R.Y.-Y.C., and G.-R.C. wrote, reviewed, and edited the manuscript. All authors have read and agreed to the published version of the manuscript.

Funding: This study was supported in part by the Ministry of Science and Technology (Taiwan; 109-2320-B-303-004-MY3), Chang Gung Memorial Hospital (Taiwan; CMRPG5J0191), the Taichung Veterans General Hospital (Taiwan), National Chung-Hsing University (Taiwan; TCVGH-NCHU1097610), and National Chiayi University (Taiwan; 109D1-100D6).

Institutional Review Board Statement: The review of our experimental protocol was conducted by National Chiayi University's Institutional Animal Care and Use Committee, who approved it under the approval No. 109019.

Informed Consent Statement: Not applicable.

Data Availability Statement: The data presented in this study are available on request from the corresponding author.

Acknowledgments: The authors would like to thank LiTzung Biotechnology, Kaohsiung, Taiwan, for providing pathological assistance for this study.

Conflicts of Interest: The authors declare no conflict of interest.

\section{Abbreviations}

$\begin{array}{ll}\text { 5-FU } & \text { 5-fluorouracil } \\ \text { mTOR } & \text { Mammalian target of rapamycin } \\ \text { COX-2 } & \text { Cyclooxygenase-2 } \\ \text { Bcl-2 } & \text { B-cell lymphoma } 2 \\ \text { BAD } & \text { Bcl-xL/Bcl-2 associated death promoter } \\ \text { VEGF } & \text { Vascular endothelial growth factor } \\ \text { EGFR } & \text { Epidermal growth factor receptor } \\ \text { TSC1 } & \text { Tuberous sclerosis 1 } \\ \text { TSC2 } & \text { Tuberous sclerosis } 2 \\ \text { ERK } & \text { Extracellular signal-related kinase } \\ \text { NSCLC } & \text { Non-small-cell lung cancer } \\ \text { SCLC } & \text { Small-cell lung cancer } \\ \text { DES } & \text { Drug-eluting stents } \\ \text { IL-1 } \beta & \text { Interleukin-1 } \beta \\ \text { IL-6 } & \text { Interleukin-6 } \\ \text { IL-10 } & \text { Interleukin-10 } \\ \text { TNF- } \alpha & \text { Tumor necrosis factor- } \alpha \\ \text { CRP } & \text { C-reactive protein } \\ \text { IKB } \alpha & \text { IkB kinase } \\ \text { NF- } \text { B } & \text { Nuclear factor } \kappa B \\ \text { AFP } & \text { Alpha-fetoprotein } \\ \text { PCNA } & \text { Proliferation of cell nuclear antigen } \\ \text { GR } & \text { Gefitinib resistant } \\ \text { HIF } & \text { Hypoxia-inducible factor } \\ \text { IHC } & \text { Immunohistochemical } \\ & \end{array}$




\section{Appendix A}

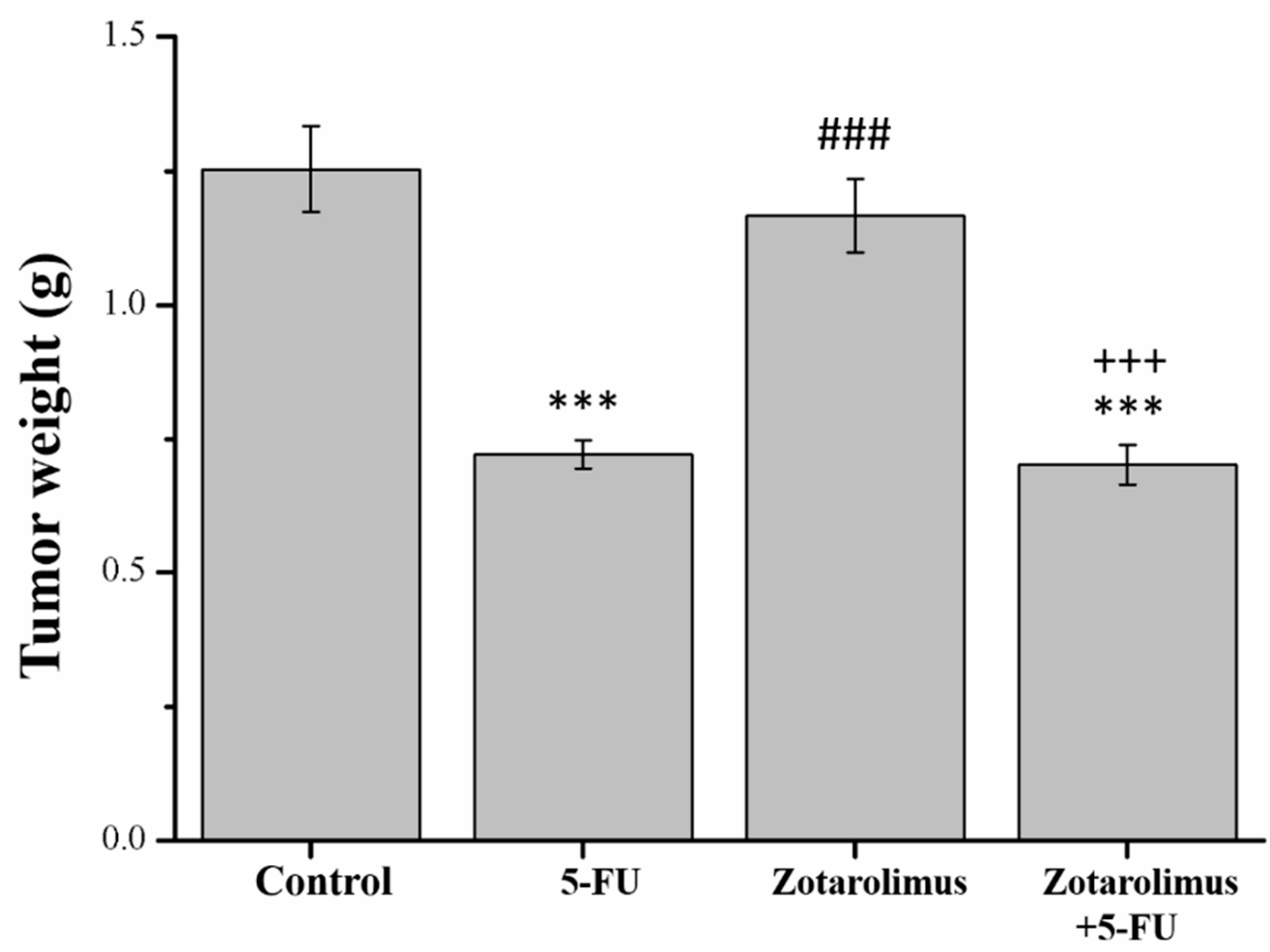

Figure A1. Tumor weight in BALB/cByJNarl mice post-sacrifice, after mice were provided different treatments, including control, 5-FU (100 mg/ kg/week), zotarolimus ( $1 \mathrm{mg} / \mathrm{kg} /$ day), and zotarolimus $(1 \mathrm{mg} / \mathrm{kg} /$ day) combined with $5-\mathrm{FU}(100 \mathrm{mg} / \mathrm{kg} /$ week $)$. All data are presented as mean \pm standard deviation, $n=7$ per group. ${ }^{* * *} p<0.001$ compared with the control group. ${ }^{\# \#} p<0.001$ compared with the 5-FU-treated group. ${ }^{+++} p<0.001$ compared with the zotarolimus-treated group.
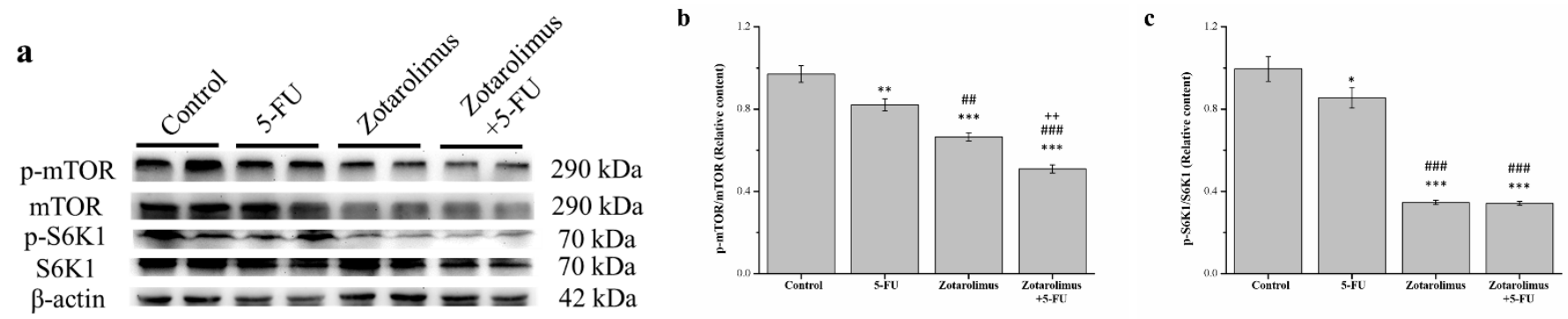

Figure A2. Western blot analysis of (a) mTOR signaling and the relative quantitative expression of (b) mTOR phosphorylation and (c) S6K1 phosphorylation in A549 tumors taken from BALB/cByJNarl mice provided with different treatments, including control, 5-FU (100 mg/ kg/week), zotarolimus ( $2 \mathrm{mg} / \mathrm{kg} /$ day), and zotarolimus ( $2 \mathrm{mg} / \mathrm{kg} /$ day) combined with 5 -FU (100 mg/kg/week). All data are presented as mean \pm standard deviation, $n=7$ per group. ${ }^{*} p<0.05,{ }^{* *} p<0.01$ and ${ }^{* * *} p<0.001$ compared with the control group. ${ }^{\# \#} p<0.01$ and ${ }^{\# \#} p<0.001$ compared with the 5-FU-treated group. ${ }^{++} p<0.01$ compared with the zotarolimus-treated group. 


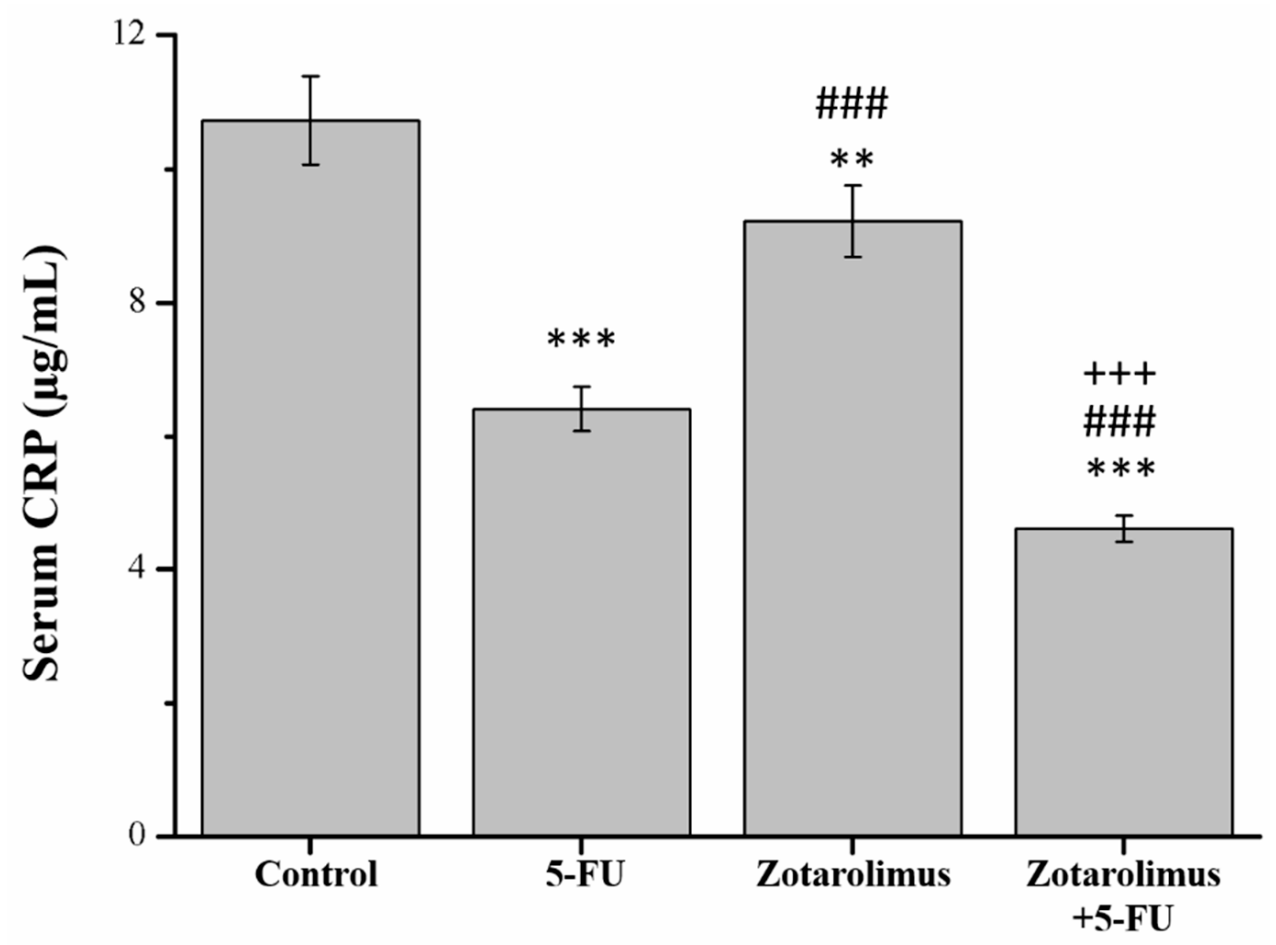

Figure A3. Changes in the serum levels of CRP measured in BALB/cByJNarl mice given different treatments, including control, 5-FU (100 mg/ kg/week), zotarolimus ( $2 \mathrm{mg} / \mathrm{kg} /$ day), and zotarolimus $(2 \mathrm{mg} / \mathrm{kg} /$ day) combined with $5-\mathrm{FU}(100 \mathrm{mg} / \mathrm{kg} /$ week $)$. All data are presented as mean \pm standard deviation, $n=7$ per group. ${ }^{* *} p<0.01$ and ${ }^{* * *} p<0.001$ compared with the control group. ${ }^{\# \# \#} p<0.001$ compared with the 5-FU-treated group. ${ }^{+++} p<0.001$ compared with the zotarolimus-treated group.

$\mathbf{a}$
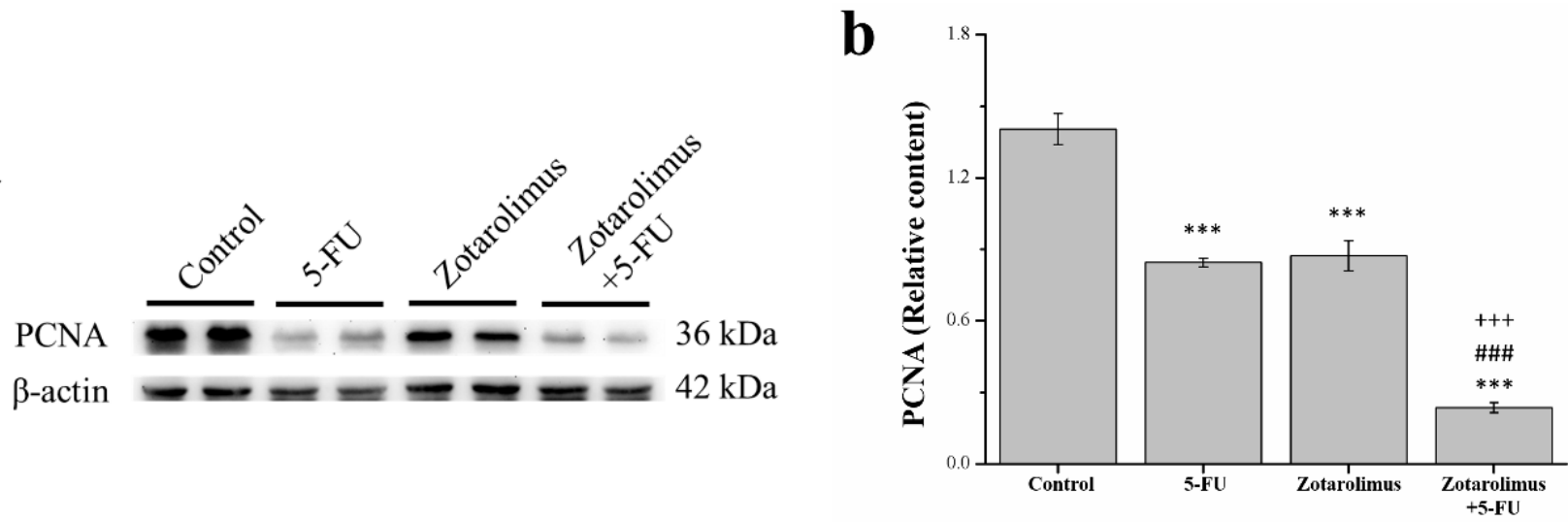

Figure A4. Western blot analysis of (a) PCNA and (b) the relative quantitative expression of PCNA in A549 tumors taken from BALB/cByJNarl mice provided with different treatments, including control, 5-FU (100 mg/ $\mathrm{kg} /$ week), zotarolimus $(2 \mathrm{mg} / \mathrm{kg} /$ day), and zotarolimus ( $2 \mathrm{mg} / \mathrm{kg} /$ day) combined with 5-FU (100 mg/kg/week). All data are presented as mean \pm standard deviation, $n=7$ per group. ${ }^{* * *} p<0.001$ compared with the control group. ${ }^{\# \# \# ~} p<0.001$ compared with the 5-FU-treated group. ${ }^{+++} p<0.001$ compared with the zotarolimus-treated group. 


\section{a}

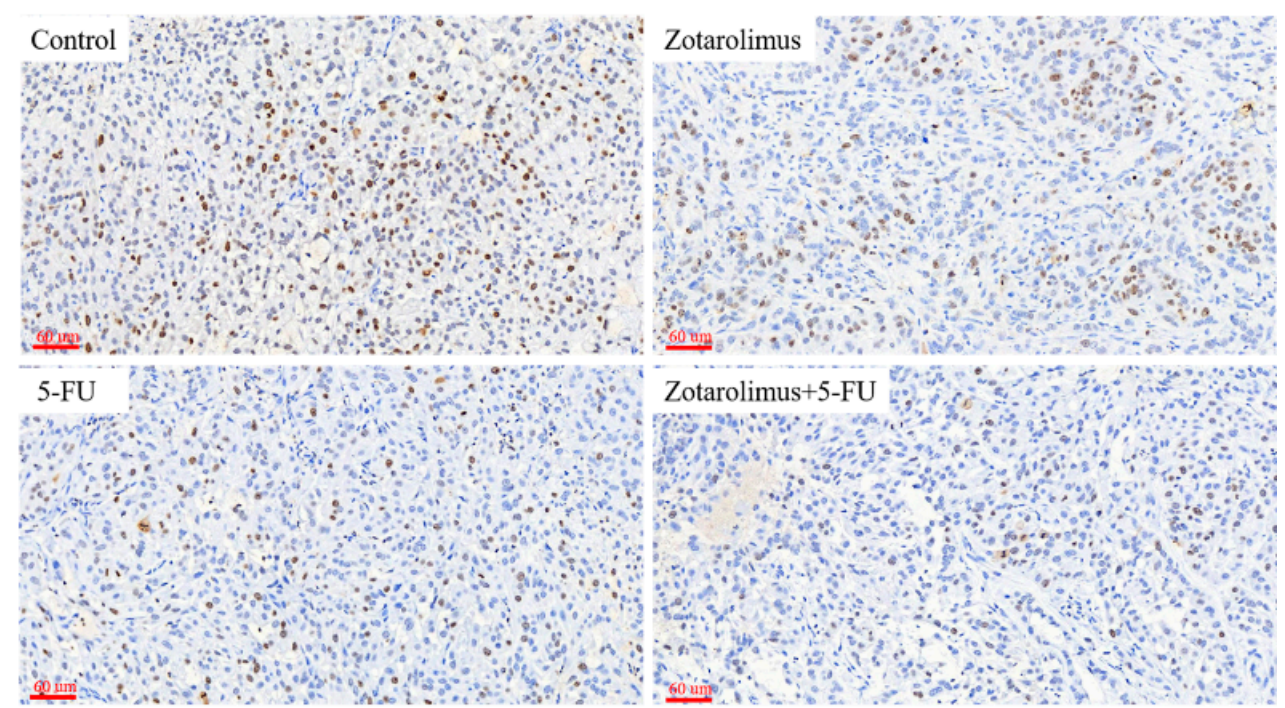

b

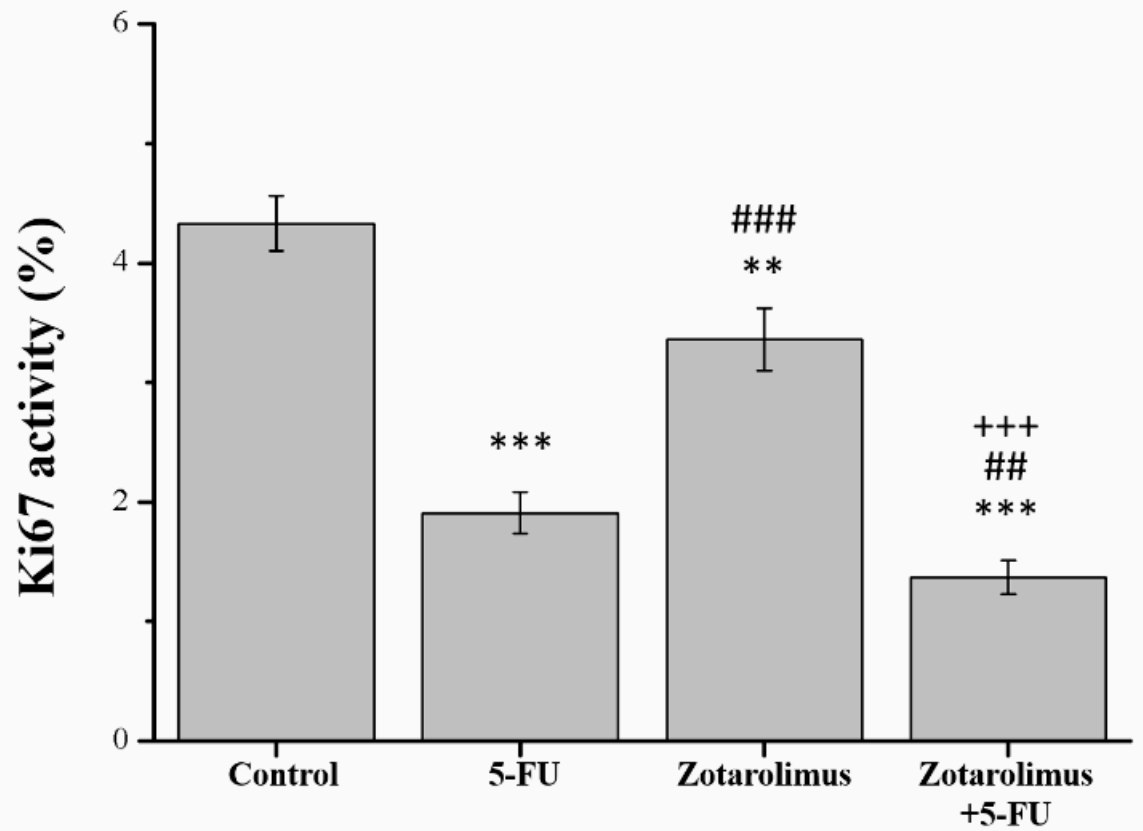

Figure A5. Immunohistochemical expression of (a) Ki67 and a comparison of the expression levels of (b) Ki67 in the A549 tumor masses from BALB/cByJNarl in control mice and mice given different treatments, including 5-FU (100 mg/ kg/week), zotarolimus ( $2 \mathrm{mg} / \mathrm{kg} /$ day), and zotarolimus ( $2 \mathrm{mg} / \mathrm{kg} /$ day) combined with 5 -FU $(100 \mathrm{mg} / \mathrm{kg} /$ week $)$. All data are presented as mean \pm standard deviation, $n=7$ per group. ${ }^{* *} p<0.01$ and ${ }^{* * *} p<0.001$ compared with the control group. \#\# $p<0.01$ and ${ }^{\# \#} p<0.001$ compared with the 5-FU-treated group. ${ }^{+++} p<0.001$ compared with the zotarolimus-treated group. Scale bars $=60 \mu \mathrm{m}$. 


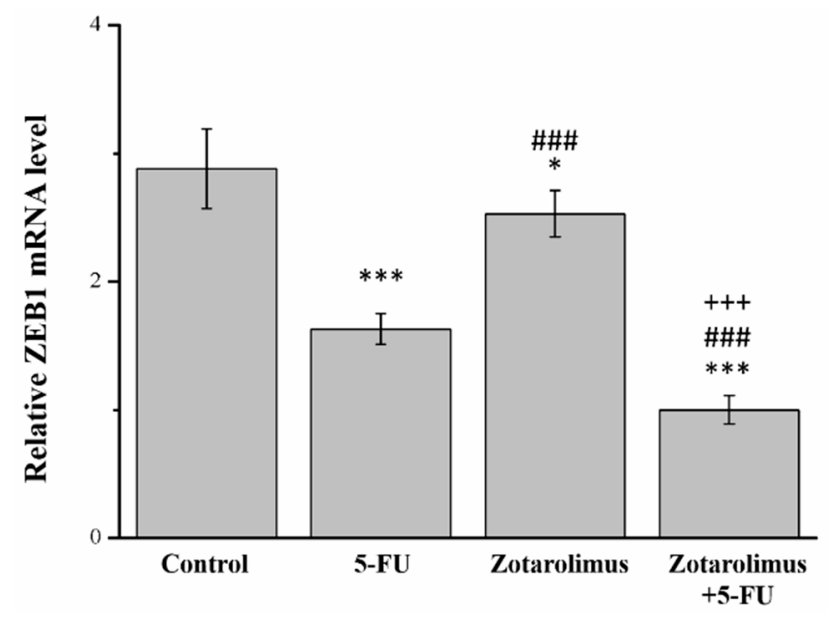

Figure A6. Relative gene mRNA expression of ZEB1 using quantitative PCR. All experiments were conducted on the A549 tumor masses from BALB/cByJNarl mice given different treatments, including control, 5-FU (100 mg/kg/week), zotarolimus (2 mg/ $\mathrm{kg} /$ day), and zotarolimus (2 mg/ $\mathrm{kg} /$ day) combined with 5 -FU $(100 \mathrm{mg} / \mathrm{kg} /$ week). All data are presented as mean \pm standard deviation, $n=7$ per group. ${ }^{*} p<0.05$ and ${ }^{* * *} p<0.001$ compared with the control group. ${ }^{\# \#} p<0.001$ compared with the 5-FU-treated group. ${ }^{+++} p<0.001$ compared with the zotarolimus-treated group.

a

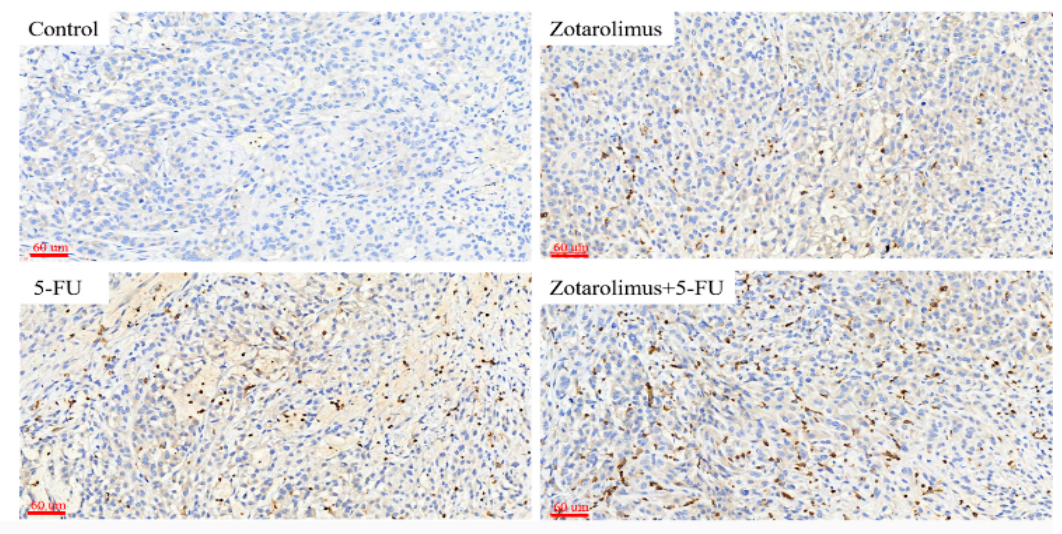

b

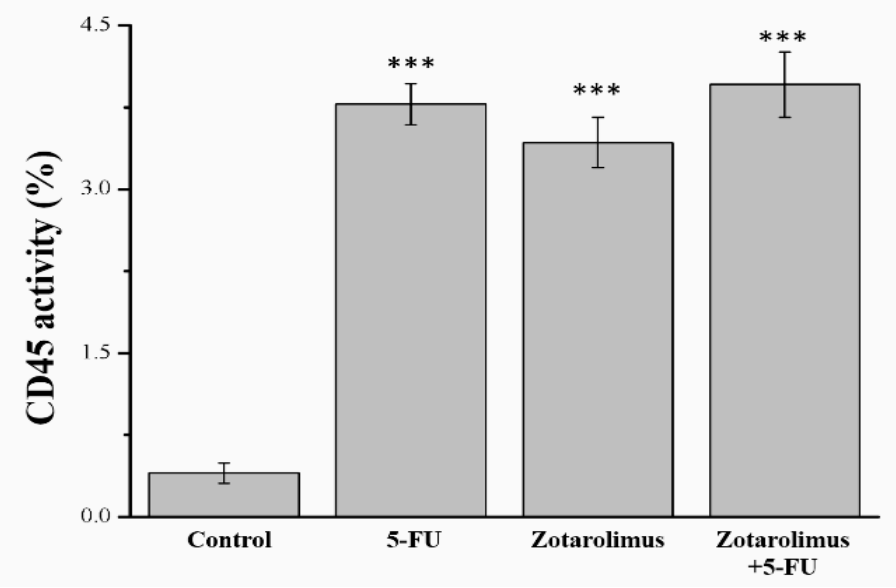

Figure A7. Immunohistochemical expression of (a) CD45 and a comparison of the expression levels of (b) CD45 in the A549 tumor masses from BALB/cByJNarl in control mice and mice given different treatments, including 5-FU (100 mg/ kg/week), zotarolimus ( $2 \mathrm{mg} / \mathrm{kg} /$ day), and zotarolimus ( $2 \mathrm{mg} / \mathrm{kg} /$ day) combined with 5-FU (100 mg/ kg/week). All data are presented as mean \pm standard deviation, $n=7$ per group. ${ }^{* * *} p<0.001$ compared with the control group. Scale bars $=60 \mu \mathrm{m}$. 


\section{References}

1. Kuo, C.N.; Liao, Y.M.; Kuo, L.N.; Tsai, H.J.; Chang, W.C.; Yen, Y. Cancers in Taiwan: Practical insight from epidemiology, treatments, biomarkers, and cost. J. Formos. Med. Assoc. 2020, 12, 1731-1741. [CrossRef]

2. World Health Organization. Latest Global Cancer Data: Cancer Burden Rises to 18.1 Million New Cases and 9.6 Million Cancer Deaths in 2018. 2018. Available online: https://https://iarc.who.int/wp-content/uploads/2018/09/pr263_E.pdf (accessed on 3 February 2021).

3. Oser, M.G.; Niederst, M.J.; Sequist, L.V.; Engelman, J.A. Transformation from non-small-cell lung cancer to small-cell lung cancer: Molecular drivers and cells of origin. Lancet Oncol. 2015, 16, e165-e172. [CrossRef]

4. Yuan, H.; Sun, B.; Gao, F.; Lan, M. Synergistic anticancer effects of andrographolide and paclitaxel against A549 NSCLC cells. Pharm. Biol. 2016, 54, 2629-2635. [CrossRef]

5. Goldstraw, P.; Ball, D.; Jett, J.R.; Le Chevalier, T.; Lim, E.; Nicholson, A.G.; Shepherd, F.A. Non-small-cell lung cancer. Lancet 2011, 378, 1727-1740. [CrossRef]

6. Huang, C.Y.; Ju, D.T.; Chang, C.F.; Reddy, P.M.; Velmurugan, B.K. A review on the effects of current chemotherapy drugs and natural agents in treating non-small cell lung cancer. Biomedicine 2017, 7, 23. [CrossRef] [PubMed]

7. Hseu, Y.C.; Chiang, Y.C.; Gowrisankar, Y.V.; Lin, K.Y.; Huang, S.T.; Shrestha, S.; Chang, G.R.; Yang, H.L. The in vitro and in vivo anticancer properties of chalcone flavokawain $\mathrm{b}$ through induction of ros-mediated apoptotic and autophagic cell death in human melanoma cells. Cancers 2020, 12, 2936. [CrossRef]

8. Saxton, R.A.; Sabatini, D.M. mTOR signaling in growth, metabolism, and disease. Cell 2017, 168, 960-976. [CrossRef] [PubMed]

9. Chang, G.R.; Chiu, Y.S.; Wu, Y.Y.; Lin, Y.C.; Hou, P.H.; Mao, F.C. Rapamycin impairs HPD-induced beneficial effects on glucose homeostasis. Br. J. Pharm. 2015, 172, 3793-3804. [CrossRef] [PubMed]

10. Zou, Z.; Tao, T.; Li, H.; Zhu, X. mTOR signaling pathway and mTOR inhibitors in cancer: Progress and challenges. Cell Biosci. 2020, 10, 31. [CrossRef] [PubMed]

11. Zoncu, R.; Efeyan, A.; Sabatini, D.M. mTOR: From growth signal integration to cancer, diabetes and ageing. Nat. Rev. Mol. Cell Biol. 2011, 12, 21-35. [CrossRef] [PubMed]

12. Cornu, M.; Albert, V.; Hall, M.N. mTOR in aging, metabolism, and cancer. Curr. Opin. Genet. Dev. 2013, 23, 53-62. [CrossRef] [PubMed]

13. Calne, R.Y.; Lim, S.; Samaan, A.; Collier, D.S.J.; Pollard, S.G.; White, D.J.G.; Thiru, S. Rapamycin for immunosuppression in organ allografting. Lancet 1989, 334, 227. [CrossRef]

14. Morice, M.C.; Serruys, P.W.; Sousa, J.E.; Fajadet, J.; Ban Hayashi, E.; Perin, M.; Molnar, F. A randomized comparison of a sirolimus-eluting stent with a standard stent for coronary revascularization. N. Engl. J. Med. 2002, 346, 1773-1780. [CrossRef]

15. Chang, G.R.; Chiu, Y.S.; Wu, Y.Y.; Chen, W.Y.; Liao, J.W.; Chao, T.H.; Mao, F.C. Rapamycin protects against high fat diet-induced obesity in C57BL/6J mice. J. Pharm. Sci. 2009, 109, 496-503. [CrossRef]

16. Aliper, A.; Jellen, L.; Cortese, F.; Artemov, A.; Karpinsky-Semper, D.; Moskalev, A.; Swick, A.G.; Zhavoronkov, A. Towards natural mimetics of metformin and rapamycin. Aging 2017, 9, 2245-2268. [CrossRef]

17. Chang, G.R.; Wu, Y.Y.; Chiu, Y.S.; Chen, W.Y.; Liao, J.W.; Hsu, H.M.; Chao, T.H.; Hung, S.W.; Mao, F.C. Long-term administration of rapamycin prevents against adiposity, but impairs glucose tolerance in high fat diet-fed KK/HlJ mice. Basic Clin. Pharm. Toxicol. 2009, 105, 188-198. [CrossRef]

18. Buellesfeld, L.; Grube, E. ABT-578-eluting stents. Herz 2004, 29, 167-170. [CrossRef]

19. Burke, S.E.; Kuntz, R.E.; Schwartz, L.B. Zotarolimus (ABT-578) eluting stents. Adv. Drug Deliv. Rev. 2006, 58, 437-446. [CrossRef] [PubMed]

20. Mehilli, J.; Richardt, G.; Valgimigli, M.; Schulz, S.; Singh, A.; Abdel-Wahab, M.; Ott, I. Zotarolimus-versus everolimus-eluting stents for unprotected left main coronary artery disease. J. Am. Coll. Cardiol. 2013, 62, 2075-2082. [CrossRef]

21. Mabuchi, S.; Altomare, D.A.; Connolly, D.C.; Klein-Szanto, A.; Litwin, S.; Hoelzle, M.K.; Testa, J.R. RAD001 (Everolimus) delays tumor onset and progression in a transgenic mouse model of ovarian cancer. Cancer Res. 2007, 67, 2408-2413. [CrossRef]

22. Cejka, D.; Preusser, M.; Woehrer, A.; Sieghart, W.; Strommer, S.; Werzowa, J.; Wacheck, V. Everolimus (RAD001) and antiangiogenic cyclophosphamide show long-term control of gastric cancer growth in vivo. Cancer Biol. Ther. 2008, 7, 1377-1385. [CrossRef] [PubMed]

23. Pawaskar, D.K.; Straubinger, R.M.; Fetterly, G.J.; Hylander, B.H.; Repasky, E.A.; Ma, W.W.; Jusko, W.J. Synergistic interactions between sorafenib and everolimus in pancreatic cancer xenografts in mice. Cancer Chemother. Pharm. 2013, 71, 1231-1240. [CrossRef]

24. Chiong, E.; Lee, I.L.; Dadbin, A.; Sabichi, A.L.; Harris, L.; Urbauer, D.; Grossman, H.B. Effects of mTOR inhibitor everolimus (RAD001) on bladder cancer cells. Clin. Cancer Res. 2011, 17, 2863-2873. [CrossRef]

25. Xiang, X.; Zhuang, L.; Chen, H.; Yang, X.; Li, H.; Li, G.; Yu, J. Everolimus inhibits the proliferation and migration of epidermal growth factor receptor-resistant lung cancer cells A549 via regulating the microRNA-4328/phosphatase and tensin homolog signaling pathway. Oncol. Lett. 2019, 18, 5269-5276. [CrossRef]

26. Yasugi, M.; Takigawa, N.; Ochi, N.; Ohashi, K.; Harada, D.; Ninomiya, T.; Kiura, K. Everolimus prolonged survival in transgenic mice with EGFR-driven lung tumors. Exp. Cell Res. 2014, 326, 201-209. [CrossRef]

27. Zhao, J.G.; Ren, K.M.; Tang, J. Overcoming 5-Fu resistance in human non-small cell lung cancer cells by the combination of 5-Fu and cisplatin through the inhibition of glucose metabolism. Tumour. Biol. 2014, 35, 12305-12315. [CrossRef] 
28. Wei, Y.; Yang, P.; Cao, S.; Zhao, L. The combination of curcumin and 5-fluorouracil in cancer therapy. Arch. Pharm. Res. 2018, 41, 1-13. [CrossRef]

29. Li, T.; Yan, G.; Bai, Y.; Wu, M.; Fang, G.; Zhang, M.; Xie, Y.; Borjigidai, A.; Fu, B. Papain bioinspired gold nanoparticles augmented the anticancer potency of 5-FU against lung cancer. J. Exp. Nanosci. 2020, 15, 109-128. [CrossRef]

30. Polk, A.; Vaage-Nilsen, M.; Vistisen, K.; Nielsen, D.L. Cardiotoxicity in cancer patients treated with 5-fluorouracil or capecitabine: A systematic review of incidence, manifestations and predisposing factors. Cancer Treat. Rev. 2013, 39, 974-984. [CrossRef]

31. Shanker, M.; Willcutts, D.; Roth, J.A.; Ramesh, R. Drug resistance in lung cancer. Lung Cancer 2010, 1, 23.

32. Hseu, Y.C.; Chang, G.R.; Pan, J.Y.; Rajendran, P.; Mathew, D.C.; Li, M.L.; Liao, J.W.; Chen, W.T.; Yang, H.L. Antrodia camphorata inhibits epithelial-to-mesenchymal transition by targeting multiple pathways in triple-negative breast cancers. J. Cell. Physiol. 2019, 234, 4125-4139. [CrossRef]

33. Desai, S.J.; Prickril, B.; Rasooly, A. Mechanisms of phytonutrient modulation of cyclooxygenase-2 (COX-2) and inflammation related to cancer. Nutr. Cancer 2018, 70, 350-375. [CrossRef]

34. Liu, T.; Zhang, L.; Joo, D.; Sun, S.C. NF-kB signaling in inflammation. Signal Transduct. Target. Ther. 2017, 2, 17023. [CrossRef]

35. Guan, X. Cancer metastases: Challenges and opportunities. Acta Pharm. Sin. B 2015, 5, 402-418. [CrossRef]

36. Souza, D.M.; Matheus, L.H.G.; Silva, C.S.; Ferreira, J.M.; Dell, H. Renal subcapsular space of Balb/c nude mice as a route for evaluating subpopulations of human bladder carcinoma cells. In Vivo 2016, 30, 383-386.

37. Zhao, M.; Tang, S.N.; Marsh, J.L.; Shankar, S.; Srivastava, R.K. Ellagic acid inhibits human pancreatic cancer growth in Balb c nude mice. Cancer Lett. 2013, 337, 210-217. [CrossRef]

38. Tian, F.; Zhang, K.; Zheng, Z. Application of immunodeficiency rats and mice and analysis of common problems in oncology research. Chin. J. Immunol. 2016, 2, 214-217.

39. Davis, N.M.; Sokolosky, M.; Stadelman, K.; Abrams, S.L.; Libra, M.; Candido, S.; McCubrey, J.A. Deregulation of the EGFR/PI3K/PTEN/Akt/mTORC1 pathway in breast cancer: Possibilities for therapeutic intervention. Oncotarget 2014, 5, 4603. [CrossRef]

40. Heras-Sandoval, D.; Pérez-Rojas, J.M.; Hernández-Damián, J.; Pedraza-Chaverri, J. The role of PI3K/AKT/mTOR pathway in the modulation of autophagy and the clearance of protein aggregates in neurodegeneration. Cell. Signal. 2014, 26, $2694-2701$. [CrossRef]

41. Hsieh, A.C.; Liu, Y.; Edlind, M.P.; Ingolia, N.T.; Janes, M.R.; Sher, A.; Ruggero, D. The translational landscape of mTOR signalling steers cancer initiation and metastasis. Nature 2012, 485, 55-61. [CrossRef]

42. Hudes, G.; Carducci, M.; Tomczak, P.; Dutcher, J.; Figlin, R.; Kapoor, A.; Motzer, R.J. Temsirolimus, interferon alfa, or both for advanced renal-cell carcinoma. N. Engl. J. Med. 2007, 356, 2271-2281. [CrossRef]

43. Motzer, R.J.; Escudier, B.; Oudard, S.; Hutson, T.E.; Porta, C.; Bracarda, S. RECORD-1 Study Group. Efficacy of everolimus in advanced renal cell carcinoma: A double-blind, randomised, placebo-controlled phase III trial. Lancet 2008, 372, 449-456. [CrossRef]

44. Ohara, T.; Takaoka, M.; Toyooka, S.; Tomono, Y.; Nishikawa, T.; Shirakawa, Y.; Naomoto, Y. Inhibition of mTOR by temsirolimus contributes to prolonged survival of mice with pleural dissemination of non-small-cell lung cancer cells. Cancer Sci. 2011, 102, 1344-1349. [CrossRef]

45. Zatelli, M.C.; Minoia, M.; Martini, C.; Tagliati, F.; Ambrosio, M.R.; Schiavon, M.; Buratto, M.; Calabrese, F.; Gentilin, E.; Cavallesco, G.; et al. Everolimus as a new potential antiproliferative agent in aggressive human bronchial carcinoids. Endocr. Relat. Cancer 2010, 17, 719-729. [CrossRef]

46. Rivera, V.M.; Squillace, R.M.; Miller, D.; Berk, L.; Wardwell, S.D.; Ning, Y.; Clackson, T. Ridaforolimus (AP23573; MK-8669), a potent mTOR inhibitor, has broad antitumor activity and can be optimally administered using intermittent dosing regimens. Mol. Cancer Ther. 2011, 10, 1059-1071. [CrossRef]

47. Cejka, D.; Preusser, M.; Fuereder, T.; Sieghart, W.; Werzowa, J.; Strommer, S.; Wacheck, V. mTOR inhibition sensitizes gastric cancer to alkylating chemotherapy in vivo. Anticancer Res. 2008, 28, 3801-3808.

48. Kamata, S.; Kishimoto, T.; Kobayashi, S.; Miyazaki, M.; Ishikura, H. Possible involvement of persistent activity of the mammalian target of rapamycin pathway in the cisplatin resistance of AFP-producing gastric cancer cells. Cancer Biol. Ther. 2007, 6, 1036-1043. [CrossRef]

49. Wong, R.S. Apoptosis in cancer: From pathogenesis to treatment. J. Exp. Clin. Cancer Res. 2011, 30, 87. [CrossRef]

50. Certo, M.; Moore, V.D.G.; Nishino, M.; Wei, G.; Korsmeyer, S.; Armstrong, S.A.; Letai, A. Mitochondria primed by death signals determine cellular addiction to antiapoptotic BCL-2 family members. Cancer Cell 2006, 9, 351-365. [CrossRef]

51. Zhao, L.; Teng, B.; Wen, L.; Feng, Q.; Wang, H.; Li, N.; Liang, Z. mTOR inhibitor AZD8055 inhibits proliferation and induces apoptosis in laryngeal carcinoma. Int. J. Clin. Exp. Med. 2014, 7, 337-347.

52. Li, T.; Xu, X.H.; Guo, X.; Yuan, T.; Tang, Z.H.; Jiang, X.M.; Lu, J.J. Activation of notch 3/c-MYC/CHOP axis regulates apoptosis and promotes sensitivity of lung cancer cells to mTOR inhibitor everolimus. Biochem. Pharm. 2020, 175, 113921. [CrossRef]

53. Ciołczyk-Wierzbicka, D.; Zarzycka, M.; Gil, D.; Laidler, P. mTOR inhibitor Everolimus-induced apoptosis in melanoma cells. Cell Commun. Signal. 2019, 13, 357-368. [CrossRef]

54. Harada, H.; Andersen, J.S.; Mann, M.; Terada, N.; Korsmeyer, S.J. p70S6 kinase signals cell survival as well as growth, inactivating the pro-apoptotic molecule BAD. Proc. Natl. Acad. Sci. USA 2001, 98, 9666-9670. [CrossRef]

55. Mantovani, A.; Allavena, P.; Sica, A.; Balkwill, F. Cancer-related inflammation. Nature 2008, 454, 436-444. [CrossRef] 
56. Beaugerie, L.; Itzkowitz, S.H. Cancers complicating inflammatory bowel disease. N. Engl. J. Med. 2015, 372, 1441-1452. [CrossRef]

57. Lee, D.F.; Kuo, H.P.; Chen, C.T.; Hsu, J.M.; Chou, C.K.; Wei, Y.; Hung, M.C. IKK $\beta$ suppression of TSC1 links inflammation and tumor angiogenesis via the mTOR pathway. Cell 2007, 130,440-455. [CrossRef]

58. Staal-van den Brekel, A.J.; Dentener, M.A.; Schols, A.M.; Buurman, W.A.; Wouters, E.F. Increased resting energy expenditure and weight loss are related to a systemic inflammatory response in lung cancer patients. J. Clin. Oncol. 1995, 13, 2600-2605. [CrossRef]

59. Hibi, M.; Murakami, M.; Saito, M.; Hirano, T.; Taga, T.; Kishimoto, T. Molecular cloning and expression of an IL-6 signal transducer, gp130. Cell 1990, 63, 1149-1157. [CrossRef]

60. Kuwata, H.; Watanabe, Y.; Miyoshi, H.; Yamamoto, M.; Kaisho, T.; Takeda, K.; Akira, S. IL-10-inducible Bcl-3 negatively regulates LPS-induced TNF- $\alpha$ production in macrophages. Blood 2003, 102, 4123-4129. [CrossRef]

61. Sheikhpour, E.; Noorbakhsh, P.; Foroughi, E.; Farahnak, S.; Nasiri, R.; Neamatzadeh, H. A survey on the role of interleukin-10 in breast cancer: A narrative. Rep. Biochem. Mol. Biol. 2018, 7, 30. [PubMed]

62. Acuner-Ozbabacan, E.S.; Engin, B.H.; Guven-Maiorov, E.; Kuzu, G.; Muratcioglu, S.; Baspinar, A.; Nussinov, R. The structural network of Interleukin-10 and its implications in inflammation and cancer. BMC Genom. 2014, 15, S2. [CrossRef]

63. Zhang, D.; Sun, M.; Samols, D.; Kushner, I. STAT3 participates in transcriptional activation of the C-reactive protein gene by interleukin-6. J. Biol. Chem. 1996, 271, 9503-9509. [CrossRef] [PubMed]

64. Koch, A.; Fohlin, H.; Sörenson, S. Prognostic significance of C-reactive protein and smoking in patients with advanced non-small cell lung cancer treated with first-line palliative chemotherapy. J. Thorac. Oncol. 2009, 4, 326-332. [CrossRef] [PubMed]

65. Sakurai, H.; Suzuki, S.; Kawasaki, N.; Nakano, H.; Okazaki, T.; Chino, A.; Saiki, I. Tumor necrosis factor- $\alpha$-induced IKK phosphorylation of NF-kB p65 on serine 536 is mediated through the TRAF2, TRAF5, and TAK1 signaling pathway. J. Biol. Chem. 2003, 278, 36916-36923. [CrossRef]

66. Karin, M.; Greten, F.R. NF-кB: Linking inflammation and immunity to cancer development and progression. Nat. Rev. Immunol. 2005, 5, 749-759. [CrossRef]

67. Pikarsky, E.; Stein, I.; Bramovitch, R.A.; Amit, S.; Kasem, S.; Gutkovich-Pyest, E.; Ben-Neriah, Y. NF-kappaB functions as a tumour promoter in inflammation-associated cancer. Nature 2004, 431, 461-466. [CrossRef]

68. DiDonato, J.A.; Mercurio, F.; Karin, M. NF-кB and the link between inflammation and cancer. Immunol. Rev. 2012, 246, 379-400. [CrossRef]

69. Qiu, X.; Mei, J.; Yin, J.; Wang, H.; Wang, J.; Xie, M. Correlation analysis between expression of PCNA, Ki-67 and COX-2 and X-ray features in mammography in breast cancer. Oncol. Lett. 2017, 14, 2912-2918. [CrossRef]

70. Cao, C.; Gao, R.; Zhang, M.; Amelio, A.L.; Fallahi, M.; Chen, Z.; Kaye, F.J. Role of LKB1-CRTC1 on glycosylated COX-2 and response to COX-2 inhibition in lung cancer. JNCI: J. Natl. Cancer Inst. 2015, 107, 45-52. [CrossRef]

71. Li, L.T.; Jiang, G.; Chen, Q.; Zheng, J.N. Ki67 is a promising molecular target in the diagnosis of cancer. Mol. Med. Rep. 2015, 11, 1566-1572. [CrossRef]

72. Massagué, J.; Blain, S.W.; Lo, R.S. TGF $\beta$ signaling in growth control, cancer, and heritable disorders. Cell 2000, 103, 295-309. [CrossRef]

73. Ciftci, K.; Su, J.; Trovitch, P.B. Growth factors and chemotherapeutic modulation of breast cancer cells. J. Pharm. Pharm. 2003, 55, 1135-1141. [CrossRef] [PubMed]

74. Johansson, E.; Grassi, E.S.; Pantazopoulou, V.; Tong, B.; Lindgren, D.; Berg, T.J.; Pietras, A. CD44 interacts with HIF-2 $\alpha$ to modulate the hypoxic phenotype of perinecrotic and perivascular glioma cells. Cell Rep. 2017, 20, 1641-1653. [CrossRef] [PubMed]

75. Park, N.R.; Cha, J.H.; Jang, J.W.; Bae, S.H.; Jang, B.; Kim, J.H.; Yoon, S.K. Synergistic effects of CD44 and TGF- $\beta 1$ through AKT/GSK-3 $\beta / \beta$-catenin signaling during epithelial-mesenchymal transition in liver cancer cells. Biochem. Biophys. Res. Commun. 2016, 477, 568-574. [CrossRef]

76. Citri, A.; Yarden, Y. EGF-ERBB signalling: Towards the systems level. Nat. Rev. Mol. Cell Biol. 2006, 7, 505-516. [CrossRef] [PubMed]

77. Bianco, R.; Garofalo, S.; Rosa, R.; Damiano, V.; Gelardi, T.; Daniele, G.; Tortora, G. Inhibition of mTOR pathway by everolimus cooperates with EGFR inhibitors in human tumours sensitive and resistant to anti-EGFR drugs. Br. J. Cancer 2008, 98, 923-930. [CrossRef]

78. Guba, M.; von Breitenbuch, P.; Steinbauer, M.; Koehl, G.; Flegel, S.; Hornung, M.; Geissler, E.K. Rapamycin inhibits primary and metastatic tumor growth by antiangiogenesis: Involvement of vascular endothelial growth factor. Nat. Med. 2002, 8, 128-135. [CrossRef] [PubMed]

79. Baselga, J.; Arteaga, C.L. Critical update and emerging trends in epidermal growth factor receptor targeting in cancer. J. Clin. Oncol. 2005, 23, 2445-2459. [CrossRef]

80. Lichtenberger, B.M.; Tan, P.K.; Niederleithner, H.; Ferrara, N.; Petzelbauer, P.; Sibilia, M. Autocrine VEGF signaling synergizes with EGFR in tumor cells to promote epithelial cancer development. Cell 2010, 140, 268-279. [CrossRef]

81. Zhang, T.; Guo, L.; Creighton, C.J.; Lu, Q.; Gibbons, D.L.; Yi, E.S.; Deng, B.; Molina, J.R.; Sun, Z.; Yang, P.; et al. A genetic cell context-dependent role for ZEB1 in lung cancer. Nat. Commun. 2016, 7, 12231. [CrossRef]

82. Jin, J.; Wang, H.; Si, J.; Ni, R.; Liu, Y.; Wang, J. ZEB1-AS1 is associated with poor prognosis in non-small-cell lung cancer and influences cell migration and apoptosis by repressing ID1. Clin. Sci. 2019, 133, 381-392. [CrossRef]

83. Dasari, S.; Tchounwou, P.B. Cisplatin in cancer therapy: Molecular mechanisms of action. Eur. J. Pharm. 2014, 740, 364-378. [CrossRef] [PubMed] 
84. Siddik, Z.H. Cisplatin: Mode of cytotoxic action and molecular basis of resistance. Oncogene 2003, 22, 7265-7279. [CrossRef] [PubMed]

85. Galluzzi, L.; Vitale, I.; Michels, J.; Brenner, C.; Szabadkai, G.; Harel-Bellan, A.; Kroemer, G.J.C.D. Systems biology of cisplatin resistance: Past, present and future. Cell Death Dis. 2014, 5, e1257. [CrossRef]

86. Yang, M.; Li, J.; Gu, P.; Fan, X. The application of nanoparticles in cancer immunotherapy: Targeting tumor microenvironment. Bioact. Mater. 2021, 6, 1973-1987. [CrossRef]

87. Geng, Y.; Shao, Y.; He, W.; Hu, W.; Xu, Y.; Chen, J.; Jiang, J. Prognostic role of tumor-infiltrating lymphocytes in lung cancer: A meta-analysis. Cell. Physiol. Biochem. 2015, 37, 1560-1571. [CrossRef]

88. Weiss, S.A.; Han, S.W.; Lui, K.; Tchack, J.; Shapiro, R.; Berman, R.; Darvishian, F. Immunologic heterogeneity of tumor-infiltrating lymphocyte composition in primary melanoma. Hum. Pathol. 2016, 57, 116-125. [CrossRef] [PubMed]

89. Xia, A.; Li, H.; Li, R.; Lu, L.; Wu, X. Co-treatment with BEZ235 enhances chemosensitivity of A549/DDP cells to cisplatin via inhibition of PI3K/Akt/mTOR signaling and downregulation of ERCC1 expression. Oncol. Rep. 2018, 40, 2353-2362. [CrossRef] [PubMed]

90. Zhang, B.; Jin, K.; Jiang, T.; Wang, L.; Shen, S.; Luo, Z.; Pang, Z. Celecoxib normalizes the tumor microenvironment and enhances small nanotherapeutics delivery to A549 tumors in nude mice. Sci. Rep. 2017, 7, 10071. [CrossRef]

91. Yi, H.; Cho, H.J.; Cho, S.M.; Lee, D.G.; El-Aty, A.A.; Yoon, S.J.; Bae, G.W.; Nho, K.; Kim, B.; Lee, C.H.; et al. Pharmacokinetic properties and antitumor efficacy of the 5-fluorouracil loaded PEG-hydrogel. BMC Cancer 2010, 10, 211. [CrossRef]

92. Chao, T.H.; Chang, G.R.; Chen, W.Y.; Chen, P.L.; Mao, F.C. The synergistic effect of rapamycin combined with 5-fluorouracil in BALB/cByJNarl mice bearing CT-26 tumor cells. Anticancer Res. 2014, 34, 3329-3336.

93. Chiu, T.Y.; Chang, G.R.; Chen, W.Y.; Chao, T.H.; Mao, F.C. The anti-cancer effects of resveratrol combined with 5-fluorouracil treatment in BALB/c mice bearing CT-26 cells. Colon Rectal. Surgeon 2016, 27, 65-73.

94. Saif, M.W.; von Borstel, R. 5-Fluorouracil dose escalation enabled with PN401 (triacetyluridine): Toxicity reduction and increased antitumor activity in mice. Cancer Chemother. Pharm. 2006, 58, 136-142. [CrossRef] [PubMed]

95. Amirouchene-Angelozzi, N.; Frisch-Dit-Leitz, E.; Carita, G.; Dahmani, A.; Raymondie, C.; Liot, G.; Schoumacher, M. The mTOR inhibitor everolimus synergizes with the PI3K inhibitor GDC0941 to enhance anti-tumor efficacy in uveal melanoma. Oncotarget 2016, 7, 23633. [CrossRef]

96. Attafi, I.M.; Bakheet, S.A.; Korashy, H.M. The role of NF-kB and AhR transcription factors in lead-induced lung toxicity in human lung cancer A549 cells. Toxicol. Mech. Methods 2020, 30, 197-207. [CrossRef] [PubMed]

97. Zeng, W.; Li, H.; Chen, Y.; Lv, H.; Liu, L.; Ran, J.; Li, H. Survivin activates NF-кB p65 via the IKK $\beta$ promoter in esophageal squamous cell carcinoma. Mol. Med. Rep. 2016, 13, 1869-1880. [CrossRef]

98. Wu, C.F.; Hou, P.H.; Mao, F.C.; Su, Y.C.; Wu, C.Y.; Yang, W.C.; Lin, C.S.; Tsai, H.P.; Liao, H.Y.; Chang, G.R. Mirtazapine reduces; adipocyte hypertrophy and increases glucose transporter expression in obese mice. Animals 2020, 10, 1423. [CrossRef] [PubMed]

99. Tsai, H.P.; Hou, P.H.; Mao, F.C.; Chang, C.C.; Yang, W.C.; Wu, C.F.; Liao, H.J.; Lin, T.C.; Chou, L.S.; Hsiao, L.W.; et al. Risperidone exacerbates glucose intolerance, nonalcoholic fatty liver disease, and renal impairment in obese mice. Int. J. Mol. Sci. 2021, 22, 409. [CrossRef] [PubMed]

100. Giacomelli, C.; Daniele, S.; Romei, C.; Tavanti, L.; Neri, T.; Piano, I.; Trincavelli, M.L. The A2B adenosine receptor modulates the epithelial-mesenchymal transition through the balance of cAMP/PKA and MAPK/ERK pathway activation in human epithelial lung cells. Front. Pharm. 2018, 9, 54. [CrossRef] 